Volume 7 | Issue 2

February 2020

\title{
From Suspicion to Sustainability in Global Supply Chains
}

Robert C. Bird

University of Connecticut, rbird@business.uconn.edu

Vivek Soundararajan

University of Bath, United Kingdom, V.Soundararajan@bath.ac.uk

Follow this and additional works at: https://scholarship.law.tamu.edu/lawreview

Part of the Law and Economics Commons, and the Operations and Supply Chain Management Commons

\section{Recommended Citation}

Robert C. Bird \& Vivek Soundararajan, From Suspicion to Sustainability in Global Supply Chains, 7 Tex. A\&M L. Rev. 383 (2020).

Available at: https://doi.org/10.37419/LR.V7.I2.3

This Article is brought to you for free and open access by Texas A\&M Law Scholarship. It has been accepted for inclusion in Texas A\&M Law Review by an authorized editor of Texas A\&M Law Scholarship. For more information, please contact aretteen@law.tamu.edu. 


\title{
FROM SUSPICION TO SUSTAINABILITY IN GLOBAL SUPPLY CHAINS
}

\author{
By: Robert C. Bird* \& Vivek Soundararajan**
}

\begin{abstract}
Global supply chains power $80 \%$ of world trade, but also host widespread environmental, labor, and human rights abuses in developing countries. Most scholarship focuses on some form of sanction to motivate supply chain members, but we propose that the fundamental problem is not insufficient punishment, but a lack of trust. Fickle tastes, incessant demands for lower prices, and spot market indifference force suppliers into a constant struggle for economic survival. No trust can grow in such an environment, and few sustainability practices can take meaningful root. Responding to multiple calls for scholarship in the supply chain literature, we propose a trust-building process by which supply chains can evolve from indifference and hostility to a relational partnership that produces joint investments in sustainable practices. The result is a supply chain that is more efficient, more humane, and embeds sustainability in the supply chain for the long-term.
\end{abstract}

\section{TABle of Contents}

I. The Precarious Environment of Sustainable Global Supply Chains .................... 388

II. Trust and Unilateral Initiatives in Supply Chain Management .............................. 395

A. The Multifaceted Role of Trust............... 395

B. Unilateral Initiatives and the Power of Strategically Conciliatory Acts......................... 398

III. Building Sustainable Global Supply Chains Under Conditions of Distrust ................ 402

A. Offer Unilateral Initiatives to Develop Elicitative Trust...................................

B. Establish Reciprocal Trust Through Recurrent Cooperation............................... 404

C. Sustain Relational Trust with Relation-Specific Investments ........................... 407

IV. Toward EFFiciency and Fairness Through Sustainable Global Supply Chains............ 410 A. Sustainable Practices in Global Supply Chains Generate Value ..............................

* Professor of Business Law and Eversource Energy Chair in Business Ethics, School of Business, University of Connecticut. Our thanks for comments and support from Gerlinde Berger-Walliser and Stephen Park. We also thank Erin Peterson and Chris Covucci for valuable research assistance. An earlier version of this Article was presented at the 2017 annual conference of the Academy of Management.

** Associate Professor in International Management, School of Management, University of Bath, United Kingdom.

DOI: https://doi.org/10.37419/LR.V7.I2.3 


\section{B. Sustainable Practices in Global Supply Chains}

Promote Fairness ........................... 414

V. Conclusion ................................ 418

Global supply chains power $80 \%$ of world trade, $60 \%$ of global production, and sustain over 450 million jobs. ${ }^{1}$ While global supply chains can generate efficiencies, ${ }^{2}$ they can also encourage a variety of harmful and unsustainable practices. Workers are subjected to dangerous working conditions, weak labor rights, violence, and torture. ${ }^{3}$ They often subsist in poverty or are even enslaved in forced labor. ${ }^{4}$ Many of the underlying problems that caused 1,134 Bangladeshi sweatshop workers to be killed in the entirely preventable Rana Plaza disaster remain firmly in place. ${ }^{5}$ Installing suicide nets to prevent supply chain

1. Following Decades of Rapid Increase, Global Supply Chains Shrink, INT'L LAB. ORG. News (May 21, 2015), http://www.ilo.org/global/about-the-ilo/newsroom/ news/WCMS_370189/lang—en/index.htm [http://perma.cc/R9VG-5JL6]; Global Supply Chains, SOLIDARITY CTR., https:/www.solidaritycenter.org/global-supply-chains/ (last visited Feb. 13, 2019) [https://perma.cc/9LZA-AWWL].

2. See, e.g., Jack G.A.J. van der Vorst et al., Simulation Modelling for Food Supply Chain Redesign; Integrated Decision Making on Product Quality, Sustainability and Logistics, 47 Int'L J. Production Res. 6611, 6612 (2009) ("We conclude that investments in [food supply chain] design should not only be aimed at improving logistics performance, but also at the preservation of food quality and environmental sustainability."); Elkafi Hassini et al., A Literature Review and a Case Study of Sustainable Supply Chains with a Focus on Metrics, 140 Int'L J. Production Econ. 69, 75, at 5.1.2 (2012) (noting that future access to capital markets may be conditioned on sustainable practices and that sustainable practices can reach new customers); Purba Rao \& Diane Holt, Do Green Supply Chains Lead to Competitiveness and Economic Performance?, 25 Int'L J. Operations \& Production Mgmt. 898, 912 (2005) (concluding that global supply chains can deliver superior economic performance).

3. See, e.g., Michael J. Maloni \& Michael E. Brown, Corporate Social Responsibility in the Supply Chain: An Application in the Food Industry, 68 J. Bus. ETHICs 35, 43 (2006). For a startling example of worker exploitation in global supply chains, see Dennis Arnold \& Kevin Hewison, Exploitation in Global Supply Chains: Burmese Workers in Mae Sot, 35 J. ConTemp. Asia 319, 319-21, 330 (2005). Supply chains also accelerate global environmental problems such as pollution, climate change, and exploitation of limited resources. Gerlinde Berger-Walliser et al., Using Proactive Legal Strategies for Corporate Environmental Sustainability, 6 Mich. J. EnvTL. \& Admin. L. 1,23 (2016). These problems have caused a hardening of once voluntary corporate social responsibility standards into legal requirements, but the long-term consequences of such hardening remain to be seen. See Gerlinde Berger-Walliser \& Inara Scott, Redefining Corporate Social Responsibility in an Era of Globalization in Regulatory Hardening, 55 Am. Bus. L.J. 167, 202-07 (2018).

4. See generally Arnold \& Hewison, supra note 3; Dana Raigrodski, Creative Capitalism and Human Trafficking: A Business Approach to Eliminate Forced Labor and Human Trafficking from Global Supply Chains, 8 WM. \& Mary Bus. L. Rev. 71, 87-88 (2016).

5. Michael Safi \& Dominic Rushe, Rana Plaza, Five Years On: Safety of Workers Hangs in Balance in Bangladesh, The Guardian (Apr. 24, 2018, 1:00 AM EDT), https://www.theguardian.com/global-development/2018/apr/24/bangladeshi-police-tar get-garment-workers-union-rana-plaza-five-years-on [https://perma.cc/5UNS-GGBX]; Press Release, Int'l Lab. Rts. F., 5 Years After Rana Plaza, What Has Changed? (Apr. 12, 2018), https://laborrights.org/releases/5-years-after-rana-plaza-what-has-changed [https://perma.cc/U7HC-6KXG]. 
workers from throwing themselves off the factory roofs is not a longterm solution. ${ }^{6}$ Thus, finding new ways to promote sustainable global supply chains advances a critical social good that is vital to the wellbeing of millions of people.

Scholars have concentrated on two mechanisms for fostering sustainable global supply chains. One perspective leverages contractual governance and the role of formal legal mechanisms. ${ }^{7}$ Under this view, sustainability problems are managed through negotiation and enforcement of agreements, prepared outcomes for unexpected events, and relying on formal institutions as a backdrop for performance. ${ }^{8}$ The second perspective emphasizes relational governance through which cooperative norms such as trust, flexibility, and solidarity arise and govern the parties. ${ }^{9}$ This perspective holds that norms act as a self-enforcing safety net against exploitation and contribute to mutual confidence, commitment, and knowledge transfer. ${ }^{10}$ An extensive literature explores the interaction and function of contractual and relational governance in order to solve a variety of transactional problems. ${ }^{11}$

Yet these two mechanisms remain incomplete. Contractual governance relies on agreements that have the credible threat of enforceability. ${ }^{12}$ Suppliers often reside in jurisdictions where contract enforcement is corrupt, weak, or absent. ${ }^{13}$ Relational governance re-

6. Larry Catá Backer, Realizing Socio-Economic Rights Under Emerging Global Regulatory Frameworks: The Potential Impact of Privatization and the Role of Companies in China and India, 45 Geo. Wash. InT'L L. Rev. 615, 662-64 \& nn. 312-17 (2013); Larry Catá Backer, Transnational Corporations' Outward Expression of Inward Self-Constitution: The Enforcement of Human Rights by Apple, Inc., 20 IND. J. Global Legal Stud. 805, 841-44 (2013).

7. Heidi Olander et al., The Dynamics of Relational and Contractual Governance Mechanisms in Knowledge Sharing of Collaborative R\&D Projects, 17 Knowledge Process Mgmt. 188, 189 (2010).

8. Laura Poppo \& Todd Zenger, Do Formal Contracts and Relational Governance Function as Substitutes or Compliments?, 23 Strategic MgMt. J. 707, 707 (2002).

9. Id. at $709-11$.

10. Id. at 710; Yikuan Lee \& S. Tamer Cavusgil, Enhancing Alliance Performance: The Effects of Contractual-Based Versus Relational-Based Governance, 59 J. Bus. REs. 896, 899 (2006).

11. Zhi Cao \& Fabrice Lumineau, Revisiting the Interplay Between Contractual and Relational Governance: A Qualitative and Meta-Analytic Investigation, 33 J. OPERATIONS MGMT. 15, 23 (2015) (conducting in part a meta-analysis of 149 studies reporting correlations of contractual and relational governance); Fabrice Lumineau \& James E. Henderson, The Influence of Relational Experience and Contractual Governance on the Negotiation Strategy in Buyer-Supplier Disputes, 30 J. Operations Mgmt. 382, 382-84 (2012); Lee \& Cavusgil, supra note 10, at 897-98.

12. Lumineau \& Henderson, supra note 11, at 394 ("This possibility (or threat) of third-party intervention and enforcement is the primary means by which contracts serve to exert control over the behavior of parties in an exchange.").

13. Galit A. Sarfaty, Shining Light on Global Supply Chains, 56 Harv. InT'L L.J. 419, 425 (2015) (citing Org. For Econ. Co-operation \& Dev., The Corporate Responsibility to Respect Human Rights in Supply Chains, 10th OECD 
lies on conditions of trust and mutual respect. Too often, however, lead firms and their supplier counterparts either do not trust one another or are overtly antagonistic. ${ }^{14}$ Lead firms treat their suppliers as unreliable, and suppliers perceive lead firms as fickle and bargain-obsessed. ${ }^{15}$ The result is an environment where neither contractual tools nor trustful relations are possible, leaving little chance for sustainability practices to penetrate the global supply chain.

How can sustainable practices be implemented when neither contractual nor relational governance can function? This question has not been addressed in the literature and is one that this Article seeks to answer. Building on our earlier work on precontractual investments, ${ }^{16}$ we propose a process that can transform transacting parties from a climate of deep distrust, or even hostility, to a trusting relational partnership that invests in joint coordination, goal-sharing, and investment. Relying on a combination of trust-based initiatives, relational investments, and the generation of shared values, a series of successful interactions over time become the "knitting thread" by which parties develop sustainable long-term relationships in global supply chains. ${ }^{17}$ These relationships not only generate value but also promote fairness for participants throughout the global supply chain. This model is summarized in Figure 1.

This work responds to various explicit calls in the literature for further research. We respond to the call that sustainable supply chain governance, while benefiting from many empirical observations, is in

Roundtable on Corporate Responsibility Discussion Paper (June 30, 2010), http://www.oecd.org/investment/mne/45535896.pdf); see also Michael Trebilcock \& Jing Leng, The Role of Formal Contract Law and Enforcement in Economic Development, 92 VA. L. REV. 1517, 1543-54 (2006). Without such institutions, the security of property rights remains impaired. Avinash Dixit, Governance Institutions and Economic Activity, 99 Am. Econ. Rev. 5, 5 (2009).

14. Peter Lund-Thomsen \& Khalid Nadvi, Applying the Atlanta Agreement on Child Labour in South Asia, in Business Regulation and Non-State Actors: Whose Standards? Whose Development?, 189-200 (Darryl Reed, Peter Utting, \& Ananya Mukherjee-Reed, eds., 2012).

15. Vivek Soundararajan \& Jill A. Brown, Voluntary Governance Mechanisms in Global Supply Chains: Beyond CSR to Stakeholder Utility Perspective, 134 J. Bus. Eтнісs 83, 97 (2016); Venkatesan Baskaran et al., Indian Textile Suppliers' Sustainability Evaluation Using the Grey Approach, 135 InT'L J. Production Econ. 647, 648 (2012) ("The research considering conventional criteria shows the criterion of 'price' as the prime concern for industries."). Li-Wen Lin, Comment, Corporate Social Accountability Standards in the Global Supply Chain: Resistance, Reconsideration, and Resolution in China, 15 CARdozo J. InT'L \& CoMP. L. 321, 324 (2007) (“[T]he product market in the developed countries has become so competitive that multinational companies are pressed to squeeze every penny out of their operations, including their supply chains. Therefore, multinational companies do not have strong incentives to consider the production processes of their suppliers in developing countries. Price is their primary, if not only, concern.").

16. Robert C. Bird \& Vivek Soundararajan, The Role of Precontractual Signals in Creating Sustainable Global Supply Chains, J. Bus. ETHICs (forthcoming 2020).

17. Evelyne Vanpoucke et al., Triggers and Patterns of Integration Initiatives in Successful Buyer-Supplier Relationships, 32 J. Operations Mgmt. 15, 15 (2014). 
need of further advancements in theory. One author team reviewing the literature of sustainability governance and supply chains concluded that, "despite the multitude of empirical observations of social and environmental reform, the literature on global chains and networks is rather weak in the theorisation of sustainability governance." 18 Further research has also been requested which recognizes the engagement of long, multi-tier supply chains, and associated suppliers, into sustainable supply chain management. ${ }^{19}$ The literature also needs to better understand how novel firm associations can bear fruit and develop into long-term relationships, a promising research direction that remains insufficiently addressed. ${ }^{20}$

This work also advances the literature on trust. Exploration of trust has taken significant root in both the law and business literatures. ${ }^{21}$ The trust literature, while rapidly maturing, has been criticized as unnecessarily pessimistic about how trust can be created in a context where standard antecedents do not exist. ${ }^{22} \mathrm{We}$ also respond to concerns that, while some inconsistencies have arisen in prior trust research, "[t]he most serious criticism is the . . inability of researchers to distinguish between the antecedents and the construct of trust itself." ${ }^{23}$ Further, while numerous antecedents of trust have been identified, ${ }^{24}$ there is limited research on how to build relational partnerships when the antecedents of trust are absent and active distrust may be present. Our work also advances the understanding of the boundaries of the trust literature as well as alternative methods of promoting cooperation when trust is absent. ${ }^{25}$

18. Simon R. Bush et al., Sustainability Governance of Chains and Networks: $A$ Review and Future Outlook, 107 J. Cleaner Production 8, 16 (2015).

19. Blandine Ageron et al., Sustainable Supply Chain Management: An Empirical Study, 140 Int'L J. Production Econ. 168, 169 (2012) (citing Stefan Seuring \& Martin Müller, From a Literature Review to a Conceptual Framework for Sustainable Supply Chain Management, 16 J. Cleaner Production 1699 (2008)).

20. Vanpoucke et al., supra note 17.

21. See, e.g., Frank B. Cross, Law and Trust, 93 GEO. L.J. 1457 (2005); Larry E. Ribstein, Law v. Trust, 81 B.U. L. Rev. 553 (2001); Julie Juan Li et al., Active Trust Development of Legal Senior Managers in International Subsidiaries, 59 J. Bus. Res. 73 (2006); Kirsimarja Blomqvist, The Many Faces of Trust, 13 Scandinavian J. MgMt. 271 (1997).

22. Richard M. Locke, Presentation at the U. of Mich. Conference on Trust, Institutions, and Globalization, Building Trust 6 (Nov. 15, 2002) (M.I.T., working paper), https://pdfs.semanticscholar.org/6436/48d319b2e8db68616dd2c06a79d5e1f8b5fd.pdf [https://perma.cc/DRG6-S3P2].

23. Harjinder Gill et al., Antecedents of Trust: Establishing a Boundary Condition for the Relation Between Propensity to Trust and Intention to Trust, 19 J. Bus. \& Psychol. 287, 288 (2005) (citing Rajeev Bhattacharya et al., A Formal Model of Trust Based on Outcomes, 23 Acad. Mgmt. Rev. 459 (1998)).

24. Paul Goodwin et al., Antecedent and Effects of Trust in Forecasting Advice, 29 InT'L J. ForecAsting 354, 355 (2013).

25. See Karen Cook et al., Cooperation Without Trust 196-97 (2005) (concluding that cooperation can be motivated through a variety of devices besides trust and noting a need for a research agenda on different forms of cooperativeness). 
Part I of this Article explores the nature and consequences of global supply chains and how lead firms and suppliers are incentivized away from sustainable action. Part II then highlights the importance of trust and also introduces the concept of unilateral initiatives as a mechanism by which suspicious parties can de-escalate their distrust and form the basis for a future partnership. Part III presents the relationbuilding process, which we divide into three sequential stages of progress. Each stage applies distinct practices and leverages different types of trust in order to build closer long-term contractual ties. Part IV examines how trusting relations encourage sustainable global supply chains. These supply chains are both value-generating and morally fair, encouraging both parties to invest in sustainable practices for their own benefit. ${ }^{26}$ Part V concludes.

\section{The Precarious Environment of Sustainable Global Supply Chains}

A supply chain is a group of linked firms that pass goods and services through a coordinated value chain that results in a final product. ${ }^{27}$ At the top of the supply chain is a "lead firm," an often large and influential western corporation, such as a clothing chain or tech company, that initiates and directs the flow of resources and information through the supply chain and sells product at retail. ${ }^{28}$ Beneath the lead firm are supply chain intermediaries who connect lead firms with suppliers, assist in component distribution, conduct advanced assembly, manage risk, and disseminate product information. ${ }^{29}$ Intermediaries serve as a bridge between the lead firm and the supplier and transmit requirements to suppliers to meet quantity, price, and delivery expectations. ${ }^{30}$ At the base of the supply chain reside the sup-

26. Takamichi Hosoda \& Stephen M. Disney, The Governing Dynamics of Supply Chains: The Impact of Altruistic Behavior, 42 Automatica 1301, 1308 (2008) (studying altruism in supply chains and finding that "an important insight from our results is that a significant amount of benefit comes from each player in the supply chain doing what is the best for itself and the supply chain, rather than doing what is the best for its own selfish interests").

27. John T. Mentzer et al., Defining Supply Chain Management, 22 J. Bus. LogisTICs 1, 3-4 (2001). A related term, "supply chain management," has been subjected to numerous attempts at definition. See Dag Naslund \& Steven Williamson, What in Management is Supply Chain Management? - A Critical Review of Definitions, Frameworks, and Terminology, 11 J. Mgmt. Pol'y \& PRAC. 11, 12 (2010) (reporting results of earlier work finding 173 definitions of supply chain management).

28. Timothy J. Sturgeon, How Do We Define Value Chains and Production Networks?, 11 (M.I.T. Industrial Performance Ctr., Working Paper No. 00-010, 2001).

29. S. David Wu, Supply Chain Intermediation: A Bargaining Theoretic Framework, in Handbook of Quantitative Supply Chain Analysis: Modeling in the E-Business Era 67, 67-68 (David Simchi-Levi et al., eds., 2004).

30. Miriam M. Wilhelm et al., Sustainability in Multi-Tier Supply Chains: Understanding the Double Agency Role of the First-Tier Supplier, 41 J. Operations Mamt. 42, 43 (2016). 
pliers, ${ }^{31}$ often small factories in developing countries that perform the initial manufacturing and fabrication with the raw materials available. ${ }^{32}$

Sustainable practices are essential for building a just supply chain. The modern notion of sustainability arises from the Bruntland Commission's definition of sustainable development as "development that meets the needs of the present without compromising the ability of future generations to meet their own needs." 33 This definition of sustainability now includes topics such as food security, workplace safety, economic growth, human health, and environmental impact of economic activity in both developed and developing nations. ${ }^{34}$ Sustainable development is a process of making sustainability a reality by improving human development in a fashion that is inclusive, connected, equitable, prudent, and secure. ${ }^{35}$

Sustainable practices are now widely viewed by organizations as an integral part of their business strategy. ${ }^{36}$ A sustainable organization contributes to sustainable development by contributing to the economic, social, and environmental well-being of a society. ${ }^{37}$ This is considered a triple bottom line of sustainable commitment. ${ }^{38}$ Sustainable

31. In this Article, we use "suppliers" to mean entities that function at the base of the supply chain or are otherwise distant in time, space, or intervening links from the lead firm.

32. See Paola Perez-Aleman \& Marion Sandilands, Building Value at the Top and the Bottom of the Global Supply Chain: MNC-NGO Partnerships, 51 Cal. Mgmt. REV. 24, 25 (2008).

33. World Comm. on Env't \& Dev., Our Common Future 43 (1985). In recognition of the Commission's chairman, Gro Harlem Bruntland, the report is often referred to as the Bruntland report or the product of the Bruntland Commission. Hilary F. French, Reforming the United Nations to Ensure Environmentally Sustainable Development, 4 Transnat'l L. \& Contemp. Probs. 559, 562 n.8 (1994).

34. Keith H. Hirokawa \& Patricia Salkin, Can Urban University Expansion and Sustainable Development Co-Exist?: A Case Study in Progress on Columbia University, 37 Fordham Urb. L.J. 637, 644 (2010); Craig R. Carter \& Dale S. Rogers, A Framework of Sustainable Supply Chain Management: Moving Toward New Theory, 38 Int'l J. Phys. Distribution \& Logistics Mgmt. 360, 363 (2008); Stephen Lee, The Food We Eat and the People Who Feed Us, 94 WASH. U. L. REv. 1249, 1260 (2017).

35. Melissa J. Markley \& Lenita Davis, Exploring Future Competitive Advantage Through Sustainable Supply Chains, 37 InT'L J. Phys. Distribution \& Logistics Mgmt. 763, 764 (2007) (citing Stuart L. Hart \& Mark B. Milstein, Creating Sustainable Value, 17 Acad. Mgmt. Executive 56 (2003)).

36. See, e.g., Davide Luzzini et al., From Sustainability Commitment to Performance: The Role of Intra- and Inter-Firm Collaborative Capabilities in the Upstream Supply Chain, 165 InT'L J. Production Econ. 51, 51 (2015).

37. Markley \& Davis, supra note 35, at 764.

38. Id.; see also Linda L. Barkacs \& Craig B. Barkacs, Fair Trade in a Wal-Mart World: What Does Globalization Portend for the Triple Bottom Line? 14 CHI.-Kent J. INT'L \& Comp. L. 1, 3-4 (2014) (summarizing the triple bottom line concept). The triple bottom line concept was first coined by John Elkington in 1997. Id. (citing JoHN Elkington, Cannibals with Forks: The Triple Bottom Line of 21st Century Business 2 (1998)). 
practices amongst linked firms can only be achieved through commitment across the supply chain. ${ }^{39}$

In theory, sustainability should trickle down throughout the supply chain. Non-governmental organizations ("NGOs") focus significantly on the problems generated by global supply chains. NGOs use their coercive power to persuade businesses to implement sustainable standards. ${ }^{40}$ The United Nations Environmental Programme further coordinates with NGOs, firms, and other parties to promote sustainable supply chain management and disseminate new approaches. ${ }^{41}$ Backed by consumer demands for better practices, ${ }^{42}$ lead firms feel the pressure to respond in order to defend their reputation and maintain customer loyalty. ${ }^{43}$

Various frictions, however, impede the diffusion of sustainable practices. Lead firms are culturally and linguistically distant from their suppliers, which can impede effective monitoring. ${ }^{44}$ Even without these barriers, lead firms cannot easily evaluate or verify the sustainable practices of their suppliers because they are often geographically distant. ${ }^{45}$ The number of suppliers can be numerous, with Walmart having over 20,000 suppliers in China alone and Nike relying on over 8,000 suppliers spread over fifty-one countries. ${ }^{46}$

Furthermore, direct monitoring necessary to ensure sustainable supplier practices may be so expensive that it erases the profitability

39. Luzzini et al., supra note 36, at 51 (citing Antony Paulraj, Understanding the Relationships Between Internal Resources and Capabilities, Sustainable Supply Management and Organizational Sustainability, J. Supply Chain Mgmt., Jan. 2011, at 19.

40. See, e.g., Sarah E. Light \& Eric W. Orts, Parallels in Public and Private Environmental Governance, 5 Mich. J. Envtl. \& Admin. L. 1, 49-50 (2015); Colin Scott, Beyond Taxonomies of Private Authority in Transnational Regulation, 13 German L.J. 1326, 1329 (2012).

41. Adefolake Adeyeye, The Role of Global Governance in CSR, 9 SANTA ClarA J. INT'L L. 147, 165 (2011).

42. See, e.g., Sophia Eckert, The Business Transparency on Trafficking and Slavery Act: Fighting Forced Labor in Complex Global Supply Chains, 12 J. InT'L Bus. \& L. 383, 407-08 (2013).

43. While self-motivated transparency by organizations can introduce important information to the public, such disclosure may remain selective and self-serving. See David Hess, The Transparency Trap: Non-Financial Disclosure and the Responsibility of Business to Respect Human Rights, 56 Am. Bus. L.J. 5, 41-42 (2019). Such disclosure has also been criticized for being ineffective in influencing capital markets and investment. See Virginia Harper Ho, Nonfinancial Risk Disclosure and the Costs of Private Ordering, 55 Aм. Bus. L.J. 407, 444-56 (2018).

44. See David A. Griffith et al., An Investigation of National Culture's Influence on Relationship and Knowledge Resources in Interorganizational Relationships Between Japan and the United States, J. InT'L Marketing, Sept. 2006, at 2, 7.

45. See Miriam Wilhelm et al., Implementing Sustainability in Multi-Tier Supply Chains: Strategies and Contingencies in Managing Sub-Suppliers, 182 InT'L J. ProducTION ECON. 196, 197 (2016).

46. Jason Brandenberger, Best-Laid Plans: Corporate Social Responsibility Often Goes Awry, 3 Ariz. J. Envtl. L \& Pol'y 1041, 1044 (2013); Kamel Mellahi et Al., The Ethical Business: Challenges and Controversies 214 (2010). 
of the exchange. ${ }^{47}$ Final products from sustainable and unsustainable facilities can be indistinguishable from one another. ${ }^{48}$ Lead firms cannot easily monitor factories that are geographically distant, culturally different, and continually shifting according to order requirements. While intermediaries can help improve efficiencies in the supply chain, their presence discourages direct contact between lead firms pressuring for sustainability and suppliers who utilize unsustainable practices.

With direct monitoring impractical, lead firms often rely on proxies that signal sustainable practices. These proxies take the form of a wide range of sustainability certifications or standards. ${ }^{49}$ These standards not only convey information, but they also communicate the legitimacy of the information to NGOs and consumers in an easy to understand message. The well-established certifications, such as SA8000, ${ }^{50}$ Fair Labor Association ("FLA"), ${ }^{51}$ and Business Social Compliance Initiative ("BSCI"), ${ }^{52}$ have the power to improve a firm's reputation and influence consumer behavior. As a result, standards and certifications represent an attractive alternative for firms seeking sus-

47. See Aaron Greiser, Defining the Outer Limits of Global Compliance Programs: Emerging Legal \& Reputational Liability in Corporate Supply Chains, 10 OR. REV. INT'L L. 285, 311-12 (2008).

48. See Lise Skov \& Janne Meier, Configuring Sustainability at Fashion Week, in Negotiating Values in the Creating Industries: Fairs, Festivals and Competitive Events 270, 273 (B. Moeran \& J. Pedersen eds., 2011) (explaining how sustainability is not visible in the aesthetic of fashion, but rather communicated indirectly through signals, and thus is subordinate to fashion's dominant logic).

49. Tim Bartley, Institutional Emergence in an Era of Globalization: The Rise of Transnational Private Regulation of Labor and Environment Conditions, 113 Ам. J. Soc. 297, 297, 303 (2007); Sebastien Mena \& Guido Palazzo, Input and Output Legitimacy of Multi-Stakeholder Initiatives, 22 Bus. ETHICs Q. 527, 534 (2012).

50. SA 8000 and other certification standards are offered by Social Accountability International, a "leading social certification standard for factories and organizations across the globe." See SA8000® Standard, Social Accountability InT'L, http:// www.sa-intl.org/index.cfm?fuseaction=Page.ViewPage\&pageId=1689 (last visited Nov. 11, 2019) [https://perma.cc/B2R9-4NQS].

51. The Fair Labor Association is a:

collaborative effort of socially responsible companies, colleges and universities, and civil society organizations, [that] create[] lasting solutions to abusive labor practices by offering tools and resources to companies, delivering training to factory workers and management, conducting due diligence through independent assessments, and advocating for greater accountability and transparency from companies, manufacturers, factories and others involved in global supply chains.

FAIr LAB. Ass'N, http://www.fairlabor.org/ (last visited Nov. 11, 2019) [https://perma .cc/CG6X-3NN3].

52. The Business Social Compliance Initiative "is a leading supply chain management system that supports companies to drive social compliance and improvements within the factories and farms in their global supply chains." What We Do, AmForI, http://www.amfori.org/content/what-we-do-0 [https://perma.cc/PS4E-X8Q2]. 
tainability compliance and are commonly used in supply chain monitoring. ${ }^{53}$

The attractiveness of sustainability certifications for lead firms, however, does not necessarily translate into an attractive option for suppliers. Although they have a useful purpose, such standards can "break down in the dilution of buyer power, and in the web of factors rooted in suppliers' traditions, beliefs, local demands, and resource dependency." 54 Additionally, lower-tier suppliers are frequently impoverished. ${ }^{55}$ Sustainability obligations can burden already fragile suppliers with the inability to profitably meet price-driven demands. ${ }^{56}$ As sustainability pressures largely fall on highly visible lead firms, small suppliers can view sustainable practices as unimportant to the preservation of their brand or reputation ${ }^{57}$ or as merely a luxury of the developed world. These attitudes, combined with pressure from lead firms that squeeze margins and demand rapid order fulfillment, can make sustainability demands seem like little more than tributes or taxes levied by economic imperialists to satiate western audiences. ${ }^{58}$

From the perspective of a supplier enduring an anonymous and hypercompetitive market, one fickle lead firm may be just like another, and there is little incentive for a supplier to make financial investments in an already precarious association. Suppliers are likely aware that the lead firm's monitoring costs are high, and it is unlikely that a lead firm or a government entity will be able to locate, let alone inspect, a wayward facility without warning. ${ }^{59}$ For example, Ban-

53. David Levy et al., The Political Dynamics of Sustainable Coffee: Contested Value Regimes and the Transformation of Sustainability, 53 J. Mgmt. Stud. 364, 382 (2016).

54. Soundararajan \& Brown, supra note 15 , at 84 .

55. Id. at 96.

56. Amrou Awaysheh \& Robert D. Klassen, The Impact of Supply Chain Structure on the Use of Supplier Socially Responsible Practices, 30 InT'L J. OPERATIONS \& PRODuCTION MgmT. 1246, 1250, 1261 (2010).

57. See Dima Jamali et al., Peculiar Strengths and Relational Attributes of SMEs in the Context of CSR, 87 J. Bus. ETHICs 355, 357 (2009)

58. Farzad Rafi Khan \& Peter Lund-Thomsen, CSR as Imperialism: Towards a Phenomenological Approach to CSR in the Developing World, 11 J. Change Mgmt. 73, 82 (2011). The authors surveying local manufacturers concluded:

[I]t is hardly surprising that many local manufacturers experienced CSR as a tool for extracting further economic surplus from them by their Western buyers. The local suppliers felt that they were compelled to pay for the CSR requirements which could be paid fully or at least partially by these customers. Western-based CSR initiatives seen in this context are thus experienced by local manufacturers as a form of economic imperialism in which a tribute or tax is levied on them by the Western brands, which may please their Western publics but does little or nothing to increase the earnings of supplier Id. firms.

59. See Mia Mahmudur Rahim, Improving Social Responsibility in RMG Industries Through a New Governance Approach in Laws, 143 J. Bus. Eтнісs 807, 811-13 (2017) (describing the spotty social responsibility practices in the Bangladeshi readymade goods industry and the capacity for evasion). 
gladesh, a major source of suppliers, has only forty-six inspectors responsible for inspecting factories in the entire country. These inspectors are also not backed by the expertise of legal counsel, which would further facilitate enforcement. ${ }^{60}$ Even if an inspection did occur, penalties for a supplier are low, and a supplier can simply re-form under another name or contract with another lead firm that is less sensitive to sustainability concerns.

From the perspective of the supplier, blunt demands from the lead firm to acquire a sustainability certificate may be interpreted as an instruction to acquire such a certificate by any means necessary. "By any means necessary," however, does not incentivize genuine fulfillment of sustainability standards, but rather the acquisition of a sustainability certification through illicit means. This surreptitious conduct creates the perception of conformance while actually subverting sustainable standards. ${ }^{61}$ Suppliers can bribe the certification inspector or falsify written records. ${ }^{62}$ Others can purchase an illicit certificate from the relevant standards authority and deliver it to the lead firm directly or through an intermediary. Larger suppliers can operate numerous factories at once, but show only a single facility for certification inspections to the outside world. ${ }^{63}$ Regardless of the mechanism, the result remains the same-suppliers conform to sustainability standards in name only, a practice referred to in the literature as "symbolic compliance" or "window dressing." 64

The result is a manifestation of the principal-agent problem, ${ }^{65}$ which appears when the interests of the entity giving direction (the principal) significantly vary from the interests of the entity receiving the instructions (the agent). ${ }^{66}$ The greater the interest divergence be-

60. Mia Mahmudur Rahim, Meta-Regulation Approach of Law: A Potential Legal Strategy to Develop Socially Responsible Business Self-Regulation in Least Developed Common Law Countries, 40 Common World L. Rev. 174, 204 (2011).

61. Soundararajan \& Brown, supra note 15, at 94, 96.

62. Vivek Soundararajan et al., Small Business and Social Irresponsibility in Developing Countries: Working Conditions and "Evasion" Institutional Work, 57 Bus. \& SOC'Y. 1301, 1315-16 (2016).

63. Robert Handfield \& Tom Linton, The Living Supply Chain: The Evolving Imperative of Operating in Real Time 168 (2017) (describing "show" and "shadow factories").

64. Soundararajan et al., supra note 62, at 1315; Fahian Anisul Huq et al., Social Management Capabilities of Multinational Buying Firms and Their Emerging Market Suppliers: An Exploratory Study of the Clothing Industry, 46 J. Operations MgmT. 19, 28 (2016); Petra Christmann \& Glen Taylor, Firm Self-Regulation Through International Certifiable Standards: Determinants of Symbolic Versus Substantive Implementation, 37 J. InT'L Bus. STud. 863, 864, 866 (2006).

65. Michael C. Jensen \& William H. Meckling, Theory of the Firm: Managerial Behavior, Agency Costs and Ownership Structure, 3 J. FIn. ECON. 305, 309, 312-13 (1976). See generally Eugene F. Fama \& Michael C. Jensen, Separation of Ownership and Control, 26 J.L. \& ECON. 301 (1983) (examining when agents do not receive wealth effects from their decisions in organizations).

66. Eric A. Zacks, The Moral Hazard of Contract Drafting, 42 FlA. ST. U. L. Rev. 991, 998-99 (2015). 
tween principal and agent, the greater the incentive for the agent to pursue her own ends rather than act in the principal's best interests when the agent is difficult to monitor. ${ }^{67}$ In the context of global supply chains, high monitoring costs inhibiting the principal and low incentives motivating the agent propel a sustainable supply chain system driven by perverse and self-defeating incentives. Supplier competition shifts from achieving sustainable goals to the acquisition of a certificate, legitimate or not, at the lowest cost. Those false certifications delivered to the lead firms are accepted and then used to deflect negative publicity. As a result, all parties are temporarily satisfied. The lead firm obtains the certification it needs to deflect public pressure. The supplier obtains the supply contract it wants by purchasing a false certification. The public is placated by the misleading assurance that it is purchasing sustainably manufactured goods. Nonetheless, genuine sustainability problems remain unaddressed. This new state of superficial sustainability continues until an NGO, public crisis, or other shock forces the lead firm to act again and restart the cycle.

In this environment, sustainable practices happen, to the extent they occur at all, through deterrence-based enforcement prompted by external forces such as NGOs demanding change. ${ }^{68}$ This approach creates a compliance "cat and mouse" game between violators of standards and those who enforce sustainable practices. This method of ensuring sustainability is inefficient and costly. NGOs are forced to expend valuable and limited resources investigating supply chains and publicizing wrongdoing. ${ }^{69}$ Lead firms compelled to aggressively investigate their suppliers for sustainable practices, especially on the heels of a scandal or a name-and-shame effort by NGOs, can provoke hostility from their suppliers and generate distrust as the overbearing lead firm intrudes into daily operations to secure necessary audits. ${ }^{70}$ These inspections interrupt suppliers and impose costs that are ultimately passed back to the lead firm and eventually to the consumer. ${ }^{71}$

"Cat and mouse" compliance is not only inefficient but also erodes the signaling power of certifications. Fake certifications dilute the legitimacy of the standard-setting market as a whole. ${ }^{72}$ Some of the

67. Id.

68. Jury Gualandris et al., Sustainable Evaluation and Verification in Supply Chains: Aligning and Leveraging Accountability to Stakeholders, 38 J. Operations Mgmt. 1, 1 (2015).

69. Sébastien Mena \& Daniel Waeger, Activism for Corporate Responsibility: Conceptualizing Private Regulation Opportunity Structures, 51 J. Mgmt. STud. 1091, 1096 (2014).

70. D. Eric Boyd et al., Corporate Social Responsibility in Global Supply Chains: A Procedural Justice Perspective, 40 Long Range Planning 341, 346 (2007); Soundararajan \& Brown, supra note 15, at 96.

71. Khalid Nadvi, Global Standards, Global Governance and the Organization of Global Value Chains, 8 J. Econ. Geography 323, 327 (2008).

72. Juliane Reinecke et al., The Emergence of a Standards Market: Multiplicity of Sustainability Standards in the Global Coffee Industry, 33 ORG. STUD. 789, 810 (2012). 
more flagrant certification failures include the discovery of child labor practices in African cocoa farms certified by UTZ and Rainforest Alliance ${ }^{73}$ and forced labor in the Fair Labor Association certified Patagonia supplier facilities in Indonesia. ${ }^{74}$ Consumers will thus be shouldered with greater search costs in order to determine legitimate certificates from fakes and may turn away from seeking sustainablysourced purchases altogether. Legitimately sustainable companies may also be impacted by the "cat and mouse" environment, as the actions of a rogue enterprise have the potential to taint the legitimacy of an entire industry and bring into question the industry's dedication to sustainability overall. Therefore, "cat and mouse" compliance serves no interest efficiently, which in turn increases the need for a solution that can unwind these negative incentives. The following Part introduces practices that will drive the effectiveness of our proposal.

\section{Trust and Unilateral INITIATIVES IN Supply Chain Management}

In contractual environments where mutual suspicion dominates and institutions are weak, specific tools can be used to repair relationships and make them more productive. In this Part, we highlight the role and importance of trust in the context of global supply chains. We also introduce to the supply chain context the concept of the unilateral initiative, which will be necessary for restoring lost trust.

\section{A. The Multifaceted Role of Trust}

Generally defined, trust is the "willingness of a party to be vulnerable to the actions of another party based on positive expectations regarding the other party's motivation and/or behavior."75 Trust can also be defined as an expectation of regular, honest, and cooperative behavior based on common and shared norms. ${ }^{76}$ More precisely, trust "is a particular level of the subjective probability with which an agent assesses that another agent or group of agents will perform a particular action, both before he can monitor such action ... and in a context

73. Child Labor and Slavery in the Chocolate Industry, Food EMPOWERMENT PROJECT, http://www.foodispower.org/slavery-chocolate/ (last visited Nov. 11, 2019) [https://perma.cc/5H3D-62TQ].

74. Gillian B. White, All Your Clothes Are Made with Exploited Labor, AtLantic (June 3, 2015), http://www.theatlantic.com/business/archive/2015/06/patagonia-laborclothing-factory-exploitation/394658/ [https://perma.cc/8565-LQCA].

75. Fabrice Lumineau, How Contracts Influence Trust and Distrust, 43 J. Mgmt. 1553, 1555 (2014).

76. Daryl Koehn, Should We Trust in Trust?, 34 Am. Bus. L.J. 183, 184 (1996) (citing Francis Fukuyama, Trust: The Social Virtues and The Creation of Prosperity 26 (1995)). Koehn, in disagreeing with Fukuyama, concludes that "[i]t may be that genuine, ethically good trust is less a matter of identical substantive positions ... and more a matter of the trustor and trustee being committed to conversing with one another in an effort to avoid error, self-righteousness, and bigotry." Id. at 203. 
in which it affects his own action." "77 Trust is based on confidence in the goodwill of another and the belief that efforts will be made that are consistent with mutual goals. ${ }^{78}$ When an individual or entity is considered trustworthy, the implicit assessment is made that it is sufficiently likely that the trusted party will perform an expected beneficial (or at least non-harmful) action that is enough for the trusting party to be willing to engage with that recipient of trust. ${ }^{79}$

Trust is believed to be an important antecedent to inter-firm cooperation. ${ }^{80}$ Trust between supply chain partners is also an important condition for long-term supply chain relationships ${ }^{81}$ and performance. ${ }^{82}$ A trustworthy supply chain also results in increased willingness to take risks, as exchange partners will show a greater tendency to share the costs of risky behavior. ${ }^{83}$ Partners that trust each other will share information ${ }^{84}$ and not behave opportunistically, even if they can gain short-term benefits by doing so. ${ }^{85}$ Trust also builds social capital, a valuable asset that encourages respect and reciprocity between contracting parties. ${ }^{86}$

A fundamental trait of trust is that it leaves the trusting party vulnerable to another. ${ }^{87}$ That vulnerability can manifest through a sus-

77. Diego Gambetta, Can We Trust Trust?, in Trust Making and Breaking in Cooperative Relations 213, 217 (D. Gambetta ed., 1988).

78. Ken G. Smith et al., Intra- and Interorganizational Cooperation: Toward a Research Agenda, 38 Acad. Mgmt. J. 7, 11 (1995) (citing Peter Smith Ring \& Andrew H. Van de Ven, Developmental Processes of Cooperative International Relationships, 19 Acad. Mgmt. Rev. 90 (1994)).

79. Gambetta, supra note 77 , at 213,217 . Conversely, an entity is deemed untrustworthy when the probability of expected beneficial and reciprocal action is sufficiently low that the trusting party refrains from trust-building measures. Id. at 217-18.

80. Smith et al., supra note 78 at 10-11 ("Although research has identified many determinants of cooperation, virtually all scholars have agreed that one especially immediate antecedent is trust.").

81. James Hill et al., The Effect of Unethical Behavior on Trust in a Buyer-Supplier Relationship: The Mediating Role of Psychological Contract Violation, 27 J. OperATions Mgmt. 281, 285 (2009).

82. Sulin Ba \& Paul Pavlou, Evidence of the Effect of Trust Building Technology in Electronic Markets: Price Premiums and Buyer Behavior, 26 Mis. Q. 243, 285 (2002).

83. Eric Fang et al., Trust at Different Organizational Levels, J. Marketing, Mar. 2008 , at 80,82 .

84. Joakim Kembro et al., Information Sharing Across Multiple Supply Chain Tiers: A Delphi Study on Antecedents, 193 InT'L J. Production Econ. 77, 79 (2017) (citing various sources).

85. See, e.g., Antonio Capaldo \& Ilaria Giannoccaro, How Does Trust Affect Performance in the Supply Chain? The Moderating Role of Interdependence, 166 INT'L J. Production ECON. 36, 37 (2015) (referring to this behavior as a source of "goodwill trust" that develops through repeated exchanges in long-term relationships).

86. Véronica H. Villena et al., The Dark Side of Buyer-Supplier Relationships: Social Capital Perspective, 29 J. Operations Mgmt. 561, 562 (2011).

87. Gregory A. Bigley \& Jone L. Pearce, Straining for Shared Meaning in Organization Science: Problems of Trust and Distrust, 23 AcAd. Mgmt. Rev. 405, 407 (1998). 
ceptibility to defection, exit, or betrayal of the relationship. ${ }^{88}$ In the commercial context, trust requires exposure to business risk. ${ }^{89}$ This risk can take the form of deceitful practices, nonperformance of the contract's terms, or exploitation of the trusting party's resources for the trusted recipient's personal gain. In environments where no trust is necessary, there is no vulnerability, and therefore no risk. ${ }^{90}$ Trust thus necessarily implies "action that puts its fate in the hand of the other party." 91

Building trust has been recommended as a solution for relation-oriented inter-organizational problems, ${ }^{92}$ including in the context of implementing sustainable supply chains. ${ }^{93}$ Scholars have suggested various trust-building mechanisms, such as promoting a willingness to communicate, ${ }^{94}$ proactive knowledge exchange, ${ }^{95}$ and making adaptations. ${ }^{96}$ However, these trust-building efforts without more may be an incomplete solution in an environment where price competition is significant, the absence of relationships is common, the geographical and cultural distance is high, and suppliers have little incentive to change their established practices. Being myopic to these conditions will lead to trust strategies that are sub-optimally effective and unnecessarily resource-intensive.

No less important is the understanding of the conditions and consequences of when trust is absent from a relationship. A lack of trust between supply chain partners has been associated with negative consequences such as inefficient and ineffective performance. ${ }^{97}$ Trust and

88. Gambetta, supra note 77 , at 219.

89. Linda D. Molm et al., Risk and Trust in Social Exchange: An Experimental Test of a Classical Proposition, 105 Aм. J. Soc. 1396, 1397 (2000).

90. Adam Lijeblad et al., Determinants of Trust for Public Lands: Fire and Fuels Management on the Bitterroot National Forest, 43 EnvTl Mgmt. 571, 572 (2009) ("Risk is inherent in trusting others, but with this definition, trusting should be viewed not as taking a risk but rather as being willing to take a risk. That is, while there can be risk without trust, there cannot be trust without risk. If one is not vulnerable, there is no need to trust others.").

91. Andrew C. Inkpen \& Steven C. Currall, The Nature, Antecedents, and Consequences of Joint Venture Trust, 4 J. InT'L Mgmt. 1, 3 (1998).

92. Jan B. Heide \& George John, Do Norms Matter in Marketing Relationships?, J. Marketing, Apr. 1992, at 32, 42; Ian R. Macneil, Power, Contract, and the Economic Model, 14 J. ECON. Issues 909, 912 (1980).

93. Thomas Y. Choi \& Janet L. Hartley, An Exploration of Supplier Selection Practices Across the Supply Chain, 14 J. Operations Mgmt. 333, 338 (1996).

94. Eva C. Kasper-Fuehrer \& Neal M. Ashkanasy, Communicating Trustworthiness and Building Trust in Interorganizational Virtual Organizations, 27 J. MGMt. 235, 240 (2001).

95. See generally Lisa C. Abrams et al., Nurturing Interpersonal Trust in Knowledge-Sharing Networks, 17 Acad. Mgmt. Executive 64, 65 (2003).

96. T.K. Das \& Bing-Sheng Teng, Between Trust and Control: Developing Confidence in Partner Cooperation in Alliances, 23 Acad. Mgmt. Rev. 491, 499 (1998).

97. Ik-Whan G. Kwon \& Taewon Suh, Factors Affecting the Level of Trust and Commitment in Supply Chain Relationships, J. Supply Chain Mgmt., Apr. 2004, at 4; Keah Choon Tan, Supply Chain Management: Practices, Concerns, and Performance Issues, J. Supply Chain Mgmt., Dec. 2002, at 42, 48. 
commitment are related to each other such that a lower level of trust leads to a lower level of commitment between supply chain partners. ${ }^{98}$ Lack of trust also makes it impossible for partners to create innovative value-added activities, including those related to sustainability. In addition, lack of trust creates a condition where supply chain partners spend their time and energy on evaluating the integrity, reliability, or trustworthiness of their partners rather than cooperatively improving processes and operations. This in turn impairs productivity and increases agency and transaction costs. ${ }^{99}$

A lack of trust can also devolve into distrust. Distrust arises when one party concludes that the other does not share similar key values. Further, distrust may arise when one party concludes that disruption of relational expectations is expected and generalizable. ${ }^{100}$ Trust and distrust are not necessarily symmetrical, as they are the sources for different motivations and have different implications for individual parties and society. ${ }^{101}$ Distrust can arise in the sustainable supply chain context when suppliers evade lead firm expectations and lead firms engage in unfair treatment of suppliers. ${ }^{102}$ Distrust can turn an otherwise indifferent relationship into a hostile one, whereby supply chain participants perform the minimum necessary to complete a transaction, refuse to invest further, and are willing to exploit the association when the opportunity arises. There is no willingness by either party to accept vulnerability in exchange for positive expectations of behavior. ${ }^{103}$ Active distrust makes conditions in which it is nearly impossible for trusting behavior to develop organically.

\section{B. Unilateral Initiatives and the Power of Strategically Conciliatory Acts}

Trust alone cannot always repair a relationship, and trust is not always reciprocated merely because it is offered. Key determinant antecedents of trust, such as prior experience, habitualization, and

98. Robert M. Morgan \& Shelby D. Hunt, The Commitment-Trust Theory of Relationship Marketing, J. Marketing, July 1994, at 20, 24.

99. See generally Tan, supra note 97 , at $42-53$.

100. Sim B. Sitkin \& Nancy L. Roth, Explaining the Limited Effectiveness of Legalistic "Remedies" for Trust/Distrust, 4 OrG. ScI. 367, 368 (1993).

101. Russell Hardin, Distrust, 81 B.U. L. Rev. 495, 497-500 (2001).

102. Peter Lund-Thomsen \& Adam Lindgreen, Corporate Social Responsibility in Global Value Chains: Where Are We Now and Where Are We Going?, 123 J. Bus. Eтнісs 11, 18 (2013).

103. Mark A. Serva et al., The Reciprocal Nature of Trust: A Longitudinal Study of Interacting Teams, 26 J. Org. Behav. 625, 626 (2005); Denise M. Rousseau et al., Not So Different After All: A Cross-Discipline View of Trust, 23 Acad. Mgmt. Rev. 393, 394 (1998) (explaining that "confident expectations and a willingness to be vulnerable are critical components of all definitions of trust reflected in the articles [in the special issue on trust]"). 
assessment of competence, may not be available to either party. ${ }^{104}$ When these antecedents are absent, trust may not have the necessary environment in which to develop. When a lack of trust or active distrust exists, trust must be built incrementally in order for it to be sustainable over time. In situations where trust is absent or distrust reigns, unilateral initiatives can bridge the gap between suspicion and solidarity.

A unilateral initiative is defined as an action that is voluntary or conciliatory and is presented to one party for the benefit of another. ${ }^{105}$ The action is not conditioned on prior contact or the expectation of a response from the other side. The action can be real, such as a payment or concession, or status oriented, such as an award or recognition, or a combination of both. ${ }^{106}$ Unilateral initiatives are most effective when they are small, conciliatory, and capable of symbolism of further engagement. ${ }^{107}$

A unilateral initiative is not a gift, but a tactical approach to bargaining. Unilateral initiatives structure the actions and counteractions of parties in order to achieve a series of specific objectives. ${ }^{108}$ Such objectives may be to test the other side's reliability, clarify unresolved questions, present a shared identity, or construct contractual norms. If the recipient of the initiative is interested in pursuing trust-building measures, that recipient may respond with a similarly positive signal or act. Unilateral initiatives are based on the precept that gradual and reciprocal initiatives by otherwise distrustful parties can decrease tension and reduce distrust such that conciliatory and trustful actions to begin. ${ }^{109}$ The goal is to establish an initial pattern of reciprocation based upon a practice of past conduct that can break deadlocks in bargaining.

Unilateral initiatives have a proven track record in resolving intransigent multinational deadlocks. Unilateral initiatives have been credited with breaking a lock-in problem between Egypt and Israel in

104. See Inkpen \& Currall, supra note 91, at 3 (citing "prior cooperative relationships, habitualization, individual attachment, organizational fit, and assessment of partner competence" as examples of antecedents of trust in the joint venture context); Keith Blois, Are Business-to-Business Relationships Inherently Unstable?, 13 J. MARKeting Mgmt. 367, 368 (1997).

105. Michael D. Large, The Effectiveness of Gifts as Unilateral Initiatives in Bargaining, 42 Soc. Persp. 525, 526 (1999).

106. See Robert C. Bird, Defending Intellectual Property Rights in the BRIC Economies, 43 Ам. Bus. L.J. 317, 350-51 (2006) (summarizing unilateral initiatives in the international relations context).

107. Large, supra note 105, at 525.

108. Elizabeth H. Boyle \& Edward J. Lawler, Resolving Conflict Through Explicit Bargaining, 69 SOC. ForCES 1183, 1184 (1991).

109. Id. at 1184-85; see also Marc Pilisuk \& Paul Skolnick, Inducing Trust: A Test of the Osgood Proposal, 8 J. Personality \& Soc. Psychol. 121, 131 (1968) (testing Osgood's proposal and finding support for the effect of honest prior announcement of moves in interaction with conciliatory steps as productive of cooperative behavior). 
the 1970s, resulting in the signing of the Camp David Accords. ${ }^{110}$ They have also been used to de-escalate cold war tensions during the 1948-1949 blockade of West Berlin, the controversy over atmospheric nuclear testing, the 1961 Berlin crisis over western occupation of divided Berlin, and the Cuban Missile Crisis. ${ }^{111}$ Firms have also used unilateral initiatives in the business setting to thwart piracy threats in emerging markets exacerbated by a government uninterested in enforcing applicable laws. ${ }^{112}$

A unilateral initiative is not the same as a "tit for tat" exchange, which is similar to a matching-strategy whereby parties pursue a prisoner's dilemma-type bargaining game. ${ }^{113}$ In such a game, an actor selects the same action taken immediately in the past by the other party. This makes actions purely dependent on recent prior conduct and vulnerable to breakdown or devolution into a cycle of retribution. ${ }^{114}$ In addition, unilateral initiatives are neither charity nor blind faith in better behavior. Unilateral initiatives are calculated decisions to signal to the recipient that the sender is willing to engage in trustbuilding behavior. A firm should not leave itself so vulnerable that if conciliatory gestures are exploited its market position would be impaired. ${ }^{115}$ If a recipient of unilateral initiatives exploits them for his or her own advantage, the grantor of the initiatives should be prepared to retaliate or exit the relationship.

The literature on unilateral initiatives is ripe for modern application. Early research found that the graduated reductions in tension ("GRIT") strategy, the intellectual predecessor to unilateral initiatives, was more effective in inducing cooperation than competitive, reciprocal, and mixed cooperative-control strategies. ${ }^{116}$ Scholars also found that the conveyance of "firm but reasonable" concessions to a counterparty are generally the most effective at generating concessions in response. ${ }^{117}$ When unilateral initiatives were introduced, they

110. Bird, supra note 106, at 353-54. See generally Randolph "Michael" Nacol II, Negotiating on Unholy Land: The Road from Israel to Palestine, 4 PePp. Disp. Resol. L.J. 87 (2003).

111. Russell J. Leng, Reagan and the Russians: Crisis Bargaining Beliefs and the Historical Record, 78 Am. Pol. ScI. Rev. 338, 353-54 (1984).

112. Bird, supra note 106, at 354-58 (citing John Donaldson \& Rebecca Weiner, Swashbuckling the Pirates: A Communications-Based Approach to IPR Protection in China, in Chinese Intellectual Property Law and Practice 409 (Mark A. Cohen et al. eds., 1999)).

113. Samuel S. Komorita et al., Reciprocity and Cooperation in Social Dilemmas, 35 J. Conflict Resol. 494, 496 (1991).

114. Bird, supra note 106, at 351-53.

115. See Boyle \& Lawler, supra note 108, at 1200 (finding that "repeated instances of no retaliation conveyed an impression of weakness, leading the subject to view the opponent as more vulnerable to influence through punitive action.”).

116. Svenn Lindskold \& Michael G. Collins, Inducing Cooperation by Groups and Individuals: Applying Osgood's Grit Strategy, J. Conflict Resol. 679, 688 (1978).

117. See generally J.M. Chertkoff \& J.K. Esser, A Review of Experiments in Explicit Bargaining, 12 J. Experimental Soc. Psychol. 464 (1976); Edward J. Lawler \& 
resulted in greater concessions and lower hostility than a strategy of reciprocity. ${ }^{118}$ Focusing on disparate levels of power between participants, ${ }^{119}$ scholars observed that the magnitude of unilateral initiatives impacts their effectiveness depending on the relative power of the grantor and recipient of the initiative. ${ }^{120}$ Further, the benefits of cooperative reciprocity were enhanced under immediately reciprocated overtures rather than delayed responses. ${ }^{121}$ Unilateral initiatives have been most effective in situations where, similar to the relationship between lead firm and supplier in global supply chains, significant differences in bargaining power prevent overtures from being interpreted as a mere sign of weakness to be exploited. ${ }^{122}$

In the business context, the closest work to unilateral initiatives is the study of assistance-giving routines. ${ }^{123}$ Assistance-giving routines have been found to be a way to operationalize benevolent trust. ${ }^{124}$ Assistance-giving routines are also positively related to the utilization of transaction-specific investments. ${ }^{125}$ Such routines, while useful and having similarities to unilateral initiatives, are separate constructs. Assistance-giving routines are theorized to generate benevolent trust and goodwill between established relationships. ${ }^{126}$ By contrast, unilateral initiatives are designed to reduce tension between non-trusting parties that are already antagonistic, though they can be used to build trust as well. ${ }^{127}$ Unilateral initiatives are also more systematic in nature, akin to arms-length bargaining rather than altruism, and incorporate the possibility of retaliation or exit if a receiving party responds with exploitation. The strength of a unilateral initiative is its ability to gener-

Bruce K. MacMurray, Bargaining Toughness: A Qualification of Level-of-Aspiration and Reciprocity Hypotheses, 10 J. Applied. Soc. Psychol. 416, 434 (1980) (addressing the concession theories presented by Chertkoff \& Esser, supra).

118. Boyle \& Lawler, supra note 108, at 1200.

119. Edward J. Lawler et al., Unilateral Initiatives as a Conflict Resolution Strategy, 62 Soc. Psychol. Q. 240, 252-53 (1999).

120. Large, supra note 105 , at 525-42.

121. Komorita et al., supra note 113 , at 505-06.

122. Steven Lindskold \& Russell Bennett, Attributing Trust and Conciliatory Intent from Coercive Power Capability, 28 J. Personality \& Soc. Psychol. 180, 184-85 (1973) (finding that " $[\mathrm{w}] \mathrm{hen}$ the source has the clear power to arbitrarily demand 'cooperation or else' but chooses instead to attempt influence with a conciliatory initiative that can be exploited by the target, that initiative is evidently considered more genuinely accommodative than it is when used without the backing of a threat.").

123. Jeffrey H. Dyer \& Wujin Chu, The Determinants of Trust in SupplierAutomaker Relationships in the U.S., Japan, and Korea, 31 J. InT'L Bus. STuds. 259, 279 (2000); Chwo-Ming Joseph Yu et al., Formal Governance Mechanisms, Relational Governance Mechanisms, and Transaction-Specific Investments in Supplier-Manufacturer Relationships, 35 Indus. Marketing Mgmt. 128, 130, 132 (2006).

124. Yu et al., supra note 123, at 132.

125. Dyer \& Chu, supra note 123, at 279; Yu et al., supra note 123, at 132.

126. Jeffrey H. Dyer, Examining Interfirm Trust and Relationships in a Cross-National Setting, in Innovations in International and Cross-Cultural ManageMENT 222 (P. Christopher Earley \& Harbir Singh eds., 2000).

127. See David V. Edwards, International Political Analysis 49-50 (1970). 
ate trust where only distrust exists, while still allowing firms to protect their own interests. ${ }^{128}$ Nonetheless, the promising findings regarding assistance-giving routines provide support that unilateral initiatives would be effective in a global supply chain environment. Unilateral initiatives thus provide a powerful tool for building sustainable global supply chains in distrustful conditions, the subject of the next Part of this Article.

\section{Building Sustainable Global Supply Chains Under CONDITIONS OF Distrust}

Before a sustainable partnership can be developed, any distrust or hostility must be overcome. The building blocks of trust cannot be developed overnight. Incremental increases in trust quality can acclimate the parties to an evolving relation and minimize the chance for opportunism or defection. This Part introduces a three-step process that builds relations through different forms of trust and exchange.

\section{A. Offer Unilateral Initiatives to Develop Elicitative Trust}

The possibility for trust begins with the first offering of a unilateral initiative. The lead firm, possessing the greater bargaining power and being the least cost avoider if the initiative fails, ${ }^{129}$ is most likely to initiate. The initiative should be a concession or overture that can be interpreted by the trust recipient as a signal of trustworthiness or reliability. Such a concession could be the mere offering of a contract on slightly more favorable terms than the spot market. The leader firm could share otherwise unavailable information with the supplier that would incrementally help that supplier achieve its production goals. Perhaps the cheapest signal is the introduction of "cheap talk" to the other party. Cheap talk is a statement or message from one party to the other that does not impact the payoff from a future exchange. ${ }^{130}$ Cheap talk can consist of expressions of optimism toward a positive outcome, assurances of reliability, cultivation of social connectivity, or a simple expression of goodwill. ${ }^{131}$ Cheap talk is not valueless and has been shown in a variety of experiments to influence human behavior. ${ }^{132}$ Regardless of the form of the initiative, the concession or over-

128. See Leroy H. Pelton, The Psychology of Nonviolence 235-36 (1974).

129. Cf. Avery Katz, When Should an Offer Stick? The Economics of Promissory Estoppel in Preliminary Negotiations, 105 Y ALE L.J. 1249, 1273 (1996) (noting that in a contract context "other things being equal, the least-cost avoider is the party with the bargaining power ex post.").

130. Bird \& Soundararajan, supra note 16.

131. Id.

132. Id. (citing Subhasish Dugar \& Quazi Shahriar, Restricted and Free-Form Cheap-Talk and the Scope for Efficient Coordination, 109 Games \& Econ. BeHav. 294 (2018); Nejat Anbarci et al., Information Control in Reputational Cheap Talk, 106 Games \& Econ. Behav. 153 (2017); Vincent P. Crawford \& Joel Sobel, Strategic Information Transmission, 50 ECONOMETRICA 1431 (1982)). 
ture should be small in order to protect the trusting party from opportunism. Concessions, especially at this initial stage when parties distrust one another, have the potential to signal weakness and tempt the recipient to exploit the trusting party. ${ }^{133}$

Such overtures do not expose the lead firm to vulnerability as the overtures are not binding and are virtually costless to make. What such overtures do signal is a willingness to develop the building blocks of trust with the other party. If the lead firm is comfortable with a concession, it can offer the opportunity to the supplier to meet its obligations through a short-term contract. Entering into, and reliance on, a contract is not risk-free. However, in hostile environments, a shortterm contract can represent the initial step away from active mistrust.

A contract that offers stability is a trust-building measure that can facilitate initial cooperation. ${ }^{134}$ Lead firms can offer a short-term contract that involves a longer transaction or extends beyond a single transaction as a unilateral initiative. Such contracts would temporarily remove the parties from the spot market and establish a commitment for a period of time. Both sides would benefit economically from the exchanges. Suppliers benefit from the increased stability that a multiarrangement contract brings. Lead firms benefit from the successful completion of multiple contracts without the costs of locating and negotiating with another supplier.

Both parties are also still able to protect themselves from exploitation. If the supplier breaches the agreement, the lead firm can terminate the contract, cease association with the supplier, and exclude it from future supply networks. If the lead firm breaks the contract, a supplier can sue for a remedy, punish the middleman who brokered the arrangement, disseminate negative information about the lead firm, or withdraw permanently from further relations. The supplier can also begrudgingly accept the broken contract but revert to the baseline model of indifference or hostility and exploit future agreements. A jilted supplier could even retaliate by starting up an unauthorized "third shift" to produce counterfeit versions of the lead firm's goods. The counterfeit versions would then be sold on the market and

133. Large, supra note 105 , at 530 . However, in a situation where the typically more powerful lead firm is making the concession, a weakness interpretation by the small supplier is less likely, thereby enabling unilateral initiatives that are more significant in nature. $I d$. at 539 ("[I]nitiatives by lower-power parties are more likely to be attributed to weakness, so should remain small to minimize this effect, but initiatives by higher-power parties are less likely to suffer this interpretation, so larger initiatives could be more effective.").

134. See Eli Bukspan, Trust and the Triangle Expectation Model in Twenty-First Century Contract Law, 11 DePaul Bus. \& Comm. L.J. 379, 383 (2013) ("Just as the contractual institution can gain much from the existence of interpersonal trust as a cultural phenomenon, so too it can be a powerful stimuli for instilling a culture of trust, thereby contributing to stability and predictability-important foundations in the legal system in general and contract law in particular."). 
compete with, and be indistinguishable from, their genuine counterparts. ${ }^{135}$

If the contract is successful, a primitive association exists whereby the lead firm and supplier can acclimatize themselves to non-exploitative exchange. In tying themselves to a contract rather than the spot market, each side exposes initial vulnerability to accomplish the opening exchanges, a necessary condition for building trust. ${ }^{136}$ These joint commitments generate the first and most primitive type of trust, known as "elicitative trust." ${ }^{137}$ Elicitative trust behavior "is motivated by the belief or expectation that, by engaging in acts of trust themselves, one may be able to induce others to do the same." ${ }^{138}$ Elicitative trust anticipates a response and is predicated on the belief that a climate of deeper trust can eventually be created. ${ }^{139}$ The party engaging in elicitative trust acts as a "first mover" who, though vulnerable to exploitation, still persists in taking the initial action. ${ }^{140}$ A first contract cements elicitative trust through performance. Lead firms who offer a contract act as "trust volunteers" and influence suppliers who may be reticent to trust lead firms because of the fear of being abused. As lead firms and suppliers find initial contracts successful and value-generating, they may gain a certain confidence in the exchange. If the exchanges continue, the association eventually evolves, as explained in the next Section, toward a trust-based reciprocity. ${ }^{141}$

\section{B. Establish Reciprocal Trust Through Recurrent Cooperation}

Once unilateral initiatives are offered and contract terms fulfilled, a contract has been performed successfully. Both sides fulfilled their ob-

135. Peggy E. Chaudhry \& Alan Zimmerman, Protecting Your Intellectual Property Rights: Understanding the Role of Management, Governments, Consumers and Pirates 20 (2013); Thomas Moga et al., Defending Intellectual Property Rights Cases in China: Leading Lawyers on Protecting Clients' Rights in China’s Evolving IP Environment 9 (2013).

136. George G. Brenkert, Trust, Morality and International Business, 8 Bus. ЕтнICS Q. 293, 309-11 (1998); Rousseau et al., supra note 103, at 394.

137. Roderick M. Kramer et al., Collective Identity, Collective Trust, and Social Capital: Linking Group Identification and Group Cooperation, in Groups AT Work: THEORY AND RESEARCH 173, 186-87 (M. Turner ed., 2001).

138. Roderick M. Kramer et al., Collective Trust and Collective Action in Organizations: The Decision to Trust as a Social Decision, in Trust in Organizations: FronTiers of Theory and Research 357, 374 (R. Kramer \& T. Tyler eds., 1995).

139. Id.

140. Id.

141. Douglas A. Bosse et al., Stakeholders, Reciprocity, and Firm Performance, 30 Strategic Mgmt. J., 447, 454 (2009); Ranjay Gulati, Does Familiarity Breed Trust? The Implications of Repeated Ties for Contractual Choice in Alliances, 38 AcAD. MGMT. J. 85, 105 (1995) (concluding that "[o]bserving interfirm alliances over time suggests that repeated ties between firms engender trust that is manifested in the form of the contracts used to organize subsequent alliances."); Ranjay Gulati, Social Structure and Alliance Formation Patterns: A Longitudinal Analysis, 40 Admin. ScI. Q. 619, 646 (1995) (observing an interactive effect between social structure and alliance formation). 
ligations to the terms. The supplier showed its reliability to the lead firm. The lead firm displayed its willingness to source from this supplier. Each party benefits from the emerging certainty of the performance and is relieved of transaction costs arising from finding a new partner, renegotiating the contract, and adapting to new patterns of performance.

Now the exchange has the potential to become regularized. Contractual performance is not merely an exercise in repetition. Repeated exchange propagates shared values that nurture the emerging relation. ${ }^{142}$ The importance of repeated exchanges in contracts has been often emphasized. ${ }^{143}$ For example, one study of buyer-supplier exchanges concluded that "the presence of a historic pattern of exchange with a supplier raises the value to the buyer of selecting that supplier, even when procuring well-specified, highly standardized parts in a setting geared toward cost reductions." 144 The authors also concluded that "partner-specific knowledge or routines and relational contracts between organizations develop in a history-dependent way and may comprise valuable, if intangible, relational assets as well."145

Repeated exchange also reduces monitoring costs and risk of defection. As exchanges continue, partners learn one another's behavior, and consequently, how to optimally monitor each other. ${ }^{146}$ This in turn reduces the cost of monitoring, as parties learn which methods are inefficient and drop those in favor of efficient routines. ${ }^{147} \mathrm{Re}$ peated exchanges reduce defection by influencing anticipations about the future. Parties in repeated exchange come to expect, and perhaps rely on, that exchange. This in turn nudges attitudes towards cooperation and away from conflict in order to preserve that anticipation. ${ }^{148}$ Cooperation, in turn, encourages other values that increase the cost of defection. Cooperation improves contractual flexibility because parties can better adapt to unexpected disruptions to the exchange. Repeated exchange and the associated investments encourage a

142. Bosse et al., supra note 141, at 449. See also Yanfeng Zheng \& Haibin Yang, Does Familiarity Foster Innovation? The Impact of Alliance Partner Repeatedness on Breakthrough Innovation, 52 J. Mgmt. STud. 213, 227 (2015) (finding that under certain conditions, familiarity with partners can encourage breakthrough innovations).

143. Ranjay Gulati \& Maxim Sytch, Does Familiarity Breed Trust? Revisiting the Antecedents of Trust, 29 Managerial \& Decision Econ. 165, 185 (2008); Laura Poppo et al., When Can You Trust "Trust"? Calculative Trust, Relational Trust, and Supplier Performance, 37 Strategic Mgmt. J. 724, 726 (2016).

144. Daniel W. Elfenbein \& Todd R. Zenger, What is a Relationship Worth? Repeated Exchange and the Development and Deployment of Relational Capital, 25 OrG. SCI. 222, 223-24 (2014).

145. Id. at 224.

146. Sylvain Chassang, Building Routines: Learning, Cooperation, and the Dynamics of Incomplete Relational Contracts, 100 Am. Econ. Rev. 448, 453 (2010).

147. Id

148. W. Bentley MacLeod, Can Contract Theory Explain Social Preferences? 97 Am. Econ. Rev. 187, 191 (2007). 
willingness to adapt to the evolving exchange that spot market participants would typically decline. ${ }^{149}$

Repeated exchange also improves communication and the sharing of information. Communication and information sharing in turn can increase the intensity of trust in commercial transactions. ${ }^{150}$ This increased trust is particularly potent when parties share the experience of successful past cooperation between them. ${ }^{151}$ Repeated exchanges also erode cultural biases that may be held by the parties in crosscultural settings. ${ }^{152}$ Lead firms and suppliers often hail from different cultures and hold different attitudes that can impact how they interact with one another. ${ }^{153}$ As the parties deal with one another over time, actual experience overrides stereotypes and promotes further cooperation. ${ }^{154}$

As a result of repeated exchanges and associated shifts in attitudes and practices, a more evolved level of trust emerges known as "reciprocal trust." Reciprocal trust is a type of trust that forms when a party observes another's actions, reciprocates, and reconsiders its attitudes and conduct in subsequent conduct. ${ }^{155}$ Reciprocal trust is more developed than trust that relies merely on anticipated exchange. Reciprocal trust is an active process that relies on prior trust demonstrations, does not demand sharp equivalence, and begins to allow for flexibility in the relation and a focus on the long-term. The process of reciprocal trust is also dynamic and can grow depending on the attitudes, attributes, and behaviors embedded in the exchange. ${ }^{156}$ This leads to a condition in which the lead firm and supplier at this stage are now familiar with one another, stabilize their reputation judgments about one another, and solidify the emerging relation. ${ }^{157}$

149. Poppo \& Zenger, supra note 8, at 711.

150. Jeffrey H. Dyer \& Wujin Chu, The Role of Trustworthiness in Reducing Transaction Costs and Improving Performance: Empirical Evidence from the United States, Japan, and Korea, 14 Org. ScI. 57, 66 (2003); Nirmalya Kumar, The Power of Trust in Manufacturer-Retailer Relationships, Harv. Bus. Rev., Nov.-Dec. 1996, at 92, 100.

151. Christian Fischer, Trust and Communication in European Agri-Food Chains, 18 Supply Chain Mgmt 208, 212-13 (2013).

152. See Elfenbein \& Zenger, supra note 144, at 239 (noting conditions under which relational capital is most likely to form under conditions of repeated exchange); Yadong Luo, Contract, Cooperation, and Performance in International Joint Ventures, 23 Strategic Mgmt. J. 903, 917 (2002).

153. See Gareth R. Jones \& Jennifer M. George, The Experience and Evolution of Trust: Implications for Cooperation and Teamwork, 23 ACAD. MgMt. Rev. 531, 540-41 (1998).

154. Timothy L. Fort, Trust and Law's Facilitating Role, 34 Aм. Bus. L. J. 205, 211 (1996).

155. Serva et al., supra note 103, at 625-48.

156. Roger C. Mayer et al., An Integrative Model of Organizational Trust, 20 Acad. Mgmt. Rev. 709, 728 (1995); Serva et al., supra note 103, at 625-48.

157. Simone Mariconda \& Francesco Lurati, Does Familiarity Breed Stability? The Role of Familiarity in Moderating the Effects of New Information on Reputation Judgments, 68 J. Bus. Res. 957, 962 (2015). 


\section{Sustain Relational Trust with Relation-Specific Investments}

At this stage, the exchange evolves from trusting contractually to trusting relationally. Lead firms and suppliers evolve from discrete to relational contracts because they are comfortable and familiar with their values, interactions, and operations. A relational contract is a shared understanding under which parties develop a robust relationship that evolves beyond the formal contract terms. ${ }^{158}$ Parties in relational contracts emphasize mutual planning, solidarity, commitment, and particularly vigorous trust in defining and maturing their relations. ${ }^{159}$ Relational parties expect future cooperative behavior, anticipate changing needs to modify the contract, and are more tolerant of problems when they arise. ${ }^{160}$ These values, in addition to the formal terms of the contract, establish norms that maintain and deepen the relationship. ${ }^{161}$ The parties may tolerate suboptimal deviations from expectations in the short term in order to preserve the greater overall value that will be generated from the enduring relation. ${ }^{162}$

Relational contracts encourage relation-specific investments. Each side has the trust and capacity to make these investments, which counters the tendency in spot market contracting to suppress relation-specific investments to inefficiently low levels. ${ }^{163}$ Such investments in human and site-specific assets also build trust and increase supplier responsiveness. ${ }^{164}$ Suppliers may invest in special equipment that increases the efficiency of the lead firm's distinct production process. They may also invest in knowledge management mechanisms that better manage the demands of lead firms. In response to specific schedules imposed by the lead firm, the supplier may allocate labor and capital resources to better satisfy those specific requirements. The supplier may also hire workers who are specifically skilled for their

158. Scott Baker \& Albert Choi, Contract's Role in Relational Contract, 101 VA. L. Rev. 559, 560-61 (2015); Benjamin Means, A Contractual Approach to Shareholder Oppression Law, Fordham L. ReV. 1161, 1195-96 (2011).

159. See Robert C. Bird, Employment as a Relational Contract, 8 U. PA. J. LAB. \& EMP. L. 149, 151 (2005).

160. Poppo \& Zenger, supra note 8, at 721-22; Richard E. Speidel, Characteristics and Challenges of Relational Contracts, 94 Nw. U. L. REv. 823, 829 (1999); Ian R. Macneil, Contracts: Adjustment of Long-Term Economic Relations Under Classical, Neoclassical, and Relational Contract Law, 72 Nw. U. L. REv. 854, 905 (1978) (noting that in relational contracts, the "[p]ossibility of trouble [is] anticipated as normal part of relation, to be dealt with by cooperation and other restorational techniques.").

161. Lumineau \& Henderson, supra note 11, at 383.

162. David A. Griffith et al., Social Exchange in Supply Chain Relationships: The Resulting Benefits of Procedural and Distributive Justice, 24 J. Operations Mgmt. 85, 87 (2006).

163. Vincent P. Crawford, Relationship-Specific Investment, 105 Q. J. EcoN. 561, $571(1990)$.

164. Robert B. Handfield \& Christian Bechtel, The Role of Trust and Relationship Structure in Improving Supply Chain Responsiveness, 31 Indus. MARKeting Mamt. 367, 375-76 (2002). 
needs and plan hiring to accommodate the lead firm's periods of greatest demand.

Lead firms, for their part, invest by designing their distribution strategies to leverage efficiencies generated by a dedicated set of suppliers. Investments in infrastructure, either at the supplier's facility or between the facility and a transport hub, increase speed and lower transportation costs. Lead firms tailor their payments to suppliers' resource needs to ensure suppliers can smoothly meet their own financial obligations. Lead firms also share managerial knowledge and other information with the supplier in order to improve production standards. ${ }^{165}$ These investments made by lead firms and suppliers are not based merely on blind faith, but are calculated decisions validated by the concrete evidence of trust and commitment displayed by suppliers and lead firms in prior interactions.

An advantage of these relation-specific investments for the parties is that they are not easily commoditized in the wider market. A relationship is not a piece of equipment; it cannot be simply purchased on the spot market to neutralize a competitor's market advantage. It requires a genuine commitment by the parties to invest in the relationship. Such investments demand giving up immediate gains, require long-term thinking, and are party-dependent. Returns on investment are also dependent on the relationship's continuation. ${ }^{166}$ These returns become ties that bind and encourage continued investment and commitment to social action. ${ }^{167}$ The investments in these relations are also specialized and difficult to replicate, a cornerstone for achieving competitive advantage over rivals. ${ }^{168}$

The result of these investments is a higher level of trust known as "relational trust." Relational trust arises when lead firms and suppliers engage in repeated interactions over time. ${ }^{169}$ Past reliability generates positive expectations about future performance. ${ }^{170}$ Parties will have significant motivation to continue the relationship, even in the face of occasional problems in performance. ${ }^{171}$ Relationally trusting parties display goodwill, good faith, and honesty toward one another. ${ }^{172}$ Core values between partners are more closely aligned. ${ }^{173}$ Attachments may form that express some modicum of empathy for

165. Hau L. Lee et al., The Value of Information Sharing in a Two-Level Supply Chain, 46 Mgmt. ScI. 626, 640 (2000).

166. Crawford, supra note 163 , at 564-65.

167. See generally Thomas Donaldson \& Thomas W. Dunfee, Ties That Bind: A Social Contracts Approach to Business Ethics (1999).

168. Jay Barney, Firm Resources and Sustained Competitive Advantage, $17 \mathrm{~J}$. MgMt. 99, 107-11 (1991)

169. Rousseau et al., supra note 103, at 399.

170. Id.

171. Rousseau et al., supra note 103, at 400 ("Unmet expectations can be survived when relational trust exists, particularly if parties make an effort to restore a sense of good faith and fair dealing to their interactions.").

172. See Rousseau et al., supra note 103, at 399-400. 
the reciprocating partner. ${ }^{174}$ Relational trust is positively associated with supplier performance, especially when investments in supplierspecific assets occur in the relation. ${ }^{175}$

Relational trust can alleviate hold-up problems. ${ }^{176}$ Hold-up problems arise when the return on a firm's relation-specific investments are ex post expropriable by its trading partner. ${ }^{177}$ Relation-specific investments typically place the investor in a vulnerable position. A lead firm that has made relation-specific investments in a relationship with a supplier, such as infrastructure construction or sharing managerial expertise, can find those investments lost when the supplier leaves the relation in search of better terms elsewhere. Conversely, after a supplier has made such investments, a lead firm can renege its promise to purchase and, via efficient breach of contract, find better terms on the spot market. Attempts to protect those interests by contracts alone can constrain, but not eliminate, opportunism. ${ }^{178}$ Established trust and relational norms can alleviate the holdup problem by discouraging defection and thus encouraging those relation-specific investments that, in combination with relational planning, add long-term value.

Parties sharing relational trust can also benefit from improved information exchange. Suppliers reduce their need to continuously check for other business opportunities and need only have contingency plans in case the lead firm defects. This, in turn, lowers their cost of production which can be passed on to the lead firm. Suppliers can also better manage just-in-time and other time-based practices more efficiently as the trustworthy lead firms are expected to uphold payment and other commitments. Like suppliers, lead firms will then spend fewer resources on contingency planning that protects against defection. The likelihood that lead firms will punish a supplier or exclude a supplier from the supply chain due to wrongdoing will also decrease. Such reduced monitoring is based on both trust in the trading partner and self-interest in conserving resources. Information

173. Poppo et al., supra note 143, at 724; Peter S. Ring, Fragile and Resilient Trust and Their Roles in Economic Exchange, 35 Bus. \& Soc'y 148, 164 (1996).

174. Rousseau et al., supra note 103, at 399.

175. Poppo et al., supra note 143, at 736-37. The authors also found that calculative trust also influences supplier performance under certain conditions. Id.

176. Ernan Haruvy et al., Relationship-Specific Investment and Hold-Up Problems in Supply Chains: Theory and Experiments, 12 Bus. REs. 45, 67 (2018), https:// link.springer.com/article/10.1007/s40685-018-0068-0 [https://perma.cc/8AUL-KEEC] ("[T] he hold-up problem can be effectively mitigated in settings in which the relationship is not one shot."). See also Bengt Holmström \& John Roberts, The Boundaries of the Firm Revisited, 12 J. Econ. Persp. 73, 80-81 (1998).

177. Holmström \& Roberts, supra note 176 , at 74 \& n.2.

178. Stephen M. Bainbridge, Corporate Decisionmaking and the Moral Rights of Employees: Participatory Management and Natural Law, 43 Vill. L. ReV. 741, 813 (1998); Holmström \& Roberts, supra note 176, at 83. 
quality overall, which includes relevance, accuracy, reliability, and timeliness from the supplier, also improves for the lead firm. ${ }^{179}$

Lead firm and suppliers have come a long way from their previous state of mutual mistrust and reliance on the spot market. Once relational exchange has taken firm hold, sustainable practices are a natural consequence. The next Part shows how sustainable practices in relation-based supply chains can create value and enhance fairness for the parties involved.

\section{Toward Efficiency and Fairness Through Sustainable Global Supply Chains}

As discussed in the previous Section, parties in relation-based global supply chains experience a variety of benefits from that relationship. A lack of trust and the risk of defection are minimized. Communication is open and productive, enabling greater agility should changes be needed in production, as well as allowing for easier resolution of problems when they arise. Each party can expend fewer resources monitoring the other for compliance. Hold-up problems are discouraged by the incentives of cooperation. Overall, the supply chain becomes streamlined in a fashion that is not easily replicated by competitors.

With distrust problems minimized and value generated from the relation-based supply chain, the parties have the opportunity to invest in sustainable practices. Sustainable practices in supply chains are not merely altruistic endeavors, but also offer meaningful benefits to both lead firms and suppliers in global supply chains. This Part analyzes how sustainable practices in trust-based supply chain relationships can deliver both value and fairness for the individual parties involved.

\section{A. Sustainable Practices in Global Supply Chains Generate Value}

Although some argue that the concept of value is so vague as to be indefinable, ${ }^{180}$ the meaning of value in the organizational context is based upon the worth of a given resource in the firm. ${ }^{181} \mathrm{~A}$ resource in a firm becomes valuable if it "exploit[s] opportunities or neutralize[s] threats in a firm's environment." 182 Value originates when a firm can achieve goals at lower costs than its competitors. ${ }^{183}$ Value is also found

179. See Helena Forslund \& Patrik Jonsson, The Impact of Forecast Information Quality on Supply Chain Performance, 27 Int'L J. Operations \& Production Mgmt. 90, 93 (2007) (citing Paul M. Clikeman, Improving Information Quality, INTERnal Auditor, June 1999, at 32-33).

180. Ralph Barton Perry, The Definition of Value, 11 J. Phil. Psych \& Sci. MethODs 141, 143-45 (1914).

181. Cliff Bowman \& Véronique Ambrosini, Value Creation Versus Value Capture: Toward a Coherent Definition of Value in Strategy, 11 BRIT. J. MgmT. 1, 2 (2000).

182. Barney, supra note 168, at 106.

183. Margaret A. Peteraf, The Cornerstone of Competitive Advantage: A Resourcebased View, 14 Strat. Mgmt. J. 179, 180-81 (1993). 
in organizations when their resources enable implementation of new strategies that improve efficiency and effectiveness. ${ }^{184}$

Sustainable practices generate value for organizations. First, sustainable practices generate value through product differentiation. ${ }^{185}$ Rankings of brands according to sustainability are readily available online. ${ }^{186}$ A majority of customers would be willing to switch to a brand with similar price and quality traits if it is one that supports a good cause. ${ }^{187}$ Corporate citizenship is now a significant factor for consumers in their buying decisions. ${ }^{188}$ When customers learn of socially responsible behavior by an organization, attitudes toward their products become more positive. ${ }^{189}$

Second, sustainable practices can prevent the unexpected nameand-shame embarrassments that arise from NGO investigations and disclosure of poor business practices. ${ }^{190}$ Proactively avoiding scandal is more cost-effective than suffering public condemnation and repairing a tarnished reputation. Firms tend to have limited awareness of how to repair reputational damage,${ }^{191}$ leaving an enduring taint of corporate misbehavior on organizations that lasts well beyond the fervor of the initial scandal. ${ }^{192}$ With reputation management a high priority for corporate leaders, ${ }^{193}$ proactive investments in sustainable practices can minimize exposure to scandals that can be highly damaging for any organization. Conversely, such investments can also generate public approbation. For example, when McDonalds raised the price of the 15 million tomatoes it purchases annually by just a penny per pound in order to promote sustainable migrant work, it nearly

184. Barney, supra note 168 , at 106.

185. See Eric Lowitt, The Future of Value: How Sustainability Creates Value Through Competitive Differentiation 188-92 (2011).

186. See, e.g., RANKABRAND, https://rankabrand.org/ (last visited Feb. 12, 2019) [https://perma.cc/UR6K-3SLP]. For an example of a detailed review of a highly ranked sustainable enterprise, see How Sustainable is Lebensbaum - Tee?, RANKABRAND (Jan. 19, 2019), https://rankabrand.org/tea-brands/Lebensbaum+-+Tee [https:// perma.cc/6RMR-LP6Y].

187. C.B. Bhattacharya \& Shankar Sen, Doing Better at Doing Good: When, Why, and How Consumers Respond to Corporate Social Initiatives, 47 CAL. MgMt. Rev. 9, 9 (2004).

188. $I d$.

189. Xueming Lo \& C.B. Bhattacharya, Corporate Social Responsibility, Customer Satisfaction, and Market Value, 70 J. Marketing, Oct. 2006, at 1, 1.

190. Markley \& Davis, supra note 35, at 767.

191. Laura Poppo \& Donald J. Schepker, Repairing Public Trust in Organizations, 13 Corp. Rep. Rev. 124, 124 (2010).

192. Ronald Sims, Toward a Better Understanding of Organizational Efforts to Rebuild Reputation Following an Ethical Scandal, 90 J. Bus. Eтнісs 453, 468 (2009) ("When compared to a race, rebuilding reputation is often more like a marathon than a sprint. Unfortunately there is no completion date.").

193. Id. at 454 . 
doubled the pay received by those workers and generated positive publicity and approval. ${ }^{194}$

Third, firms pursuing sustainable practices attract talented job applicants. When Dutch IT firm Capgemini faced the difficult challenge of filling 800 information technology and management consulting positions in the Netherlands, it eschewed traditional recruitment incentives in its recruiting surveys. ${ }^{195}$ Instead of awarding respondents with a t-shirt or coffee mug for participating, Capgemini promised to fund a week of housing and schooling for impoverished Indian children. ${ }^{196}$ Nearly 10,000 people responded to the survey, 2,000 submitted viable resumes to Capgemini, and 800 candidates were quickly screened, interviewed, and hired. ${ }^{197}$ Traditional compensation packages of attractive salaries and benefits are no longer sufficient to attract the best talent. ${ }^{198}$ Young people entering the workforce-the future managers and leaders of organizations-are more concerned about the ethical values of their employers than prior generations. ${ }^{199}$ Over threequarters of Millennials would even consider taking a pay cut to work for a socially responsible enterprise. ${ }^{200}$ This effect is not confined to Millennials, ${ }^{201}$ with studies finding in various contexts that sustainable business practices attract competitive talent to the organization. ${ }^{202}$

194. Markley \& Davis, supra note 35, at 767. See also Steven Greenhouse, In Florida Tomato Fields, a Penny Buys Progress, N.Y. Times (Apr. 24, 2014), https://www .nytimes.com/2014/04/25/business/in-florida-tomato-fields-a-penny-buys-progress.html [https://perma.cc/362N-73NR].

195. Adrienne Fox, Corporate Social Responsibility Pays Off, Soc'y Hum. REsource MGmt. (Aug. 2, 2007), https://www.shrm.org/hr-today/news/hr-magazine/ pages/0807cover.aspx [https://perma.cc/K5P8-2DZ3].

196. Id.

197. Id. at 45-46.

198. Id. at 43 ("By being good corporate citizens, companies can woo top talent, engage employees and raise productivity.").

199. Matthew Jenkin, Millennials Want to Work for Employers Committed to Values and Ethics, GuARDian (May 5, 2015, 5:26 EDT), https://www.theguardian.com/ sustainable-business/2015/may/05/millennials-employment-employers-values-ethicsjobs [https://perma.cc/94D9-97AZ].

200. Cone Commc'ns, 2016 Cone Communications Employee Engagement STUdy 5 (2016).

201. For an example of research performed before Millennials entered the workforce, see Rich Strand et al., Organizational Entry Preferences Based Upon Social and Personnel Policies: An Information Integration Perspective, 27 Org. Behav. \& Hum. Performance 50, 50 (1981) (studying influence of pay, individual development, environmental responsibility, and fair employment practices on prospective job applicants).

202. See, e.g., Mohamad Abu Huzaifah bin Magbool et al., Corporate Sustainable Practices and Talent Attraction, 7 Sustainability Acct. \& Pol'y J. 539, 553-54 (2016) (finding that "organizations with high [corporate sustainable business ("CSB")] practices are perceived to be more attractive than organizations with lower CSB practices, and that job applicants' intention to join and accept a job offer are positively associated with an organization's CSB practices."); Kristin B. Backhaus et al., Exploring the Relationship Between Corporate Social Performance and Employer Attractiveness, 41 Bus. \& SoC'y 292, 312 (2002) ("Overall, our results indicate that potential job seekers are interested and concerned about a firm's record of corporate 
Fourth, sustainable practices toward others continue to impact a firm's workforce even after being hired by the firm. Previous studies have proposed that when potential employees perceive that their organization treats others fairly or behaves in a socially and environmentally responsible manner, there is a greater likelihood that they will exhibit positive attitudes and behaviors. ${ }^{203}$ Moreover, employees that perceive their organizations as dedicated to socially responsible practices have a substantially increased level of organizational commitment. ${ }^{204}$ This effect is so strong that it exceeds the influence of job satisfaction on commitment levels. ${ }^{205}$ Employees perceiving active corporate citizenship by their employers also report better engagement, connectivity, and creative involvement in the firm. ${ }^{206}$ Sustainable practices may also positively influence retention, ${ }^{207}$ employee identification with the firm, ${ }^{208}$ and meaningfulness of work. ${ }^{209}$

Fifth, suppliers can benefit from the stability that relation-based sustainable practices bring. When a lead firm has found a trustworthy supplier, it is less likely to arbitrarily choose another supplier because

social performance when considering firms as prospective employers."). The authors also found "somewhat suprising[ly]" that "issues that would seem to be most salient to job seekers, those issues that have a direct relationship to their daily lives, were less important than broader issues" such as corporate social performance. Id. at 313.

203. Sean Valentine \& Gary Fleischman, Ethics Programs, Perceived Corporate Social Responsibility and Job Satisfaction, 77 J. Bus. ETHICs 159, 166 (2008) (finding that "perceived CSR plays a mediating role in the relationship between ethics programs and job satisfaction"); Deborah E. Rupp et al., Employee Reactions to Corporate Social Responsibility: An Organizational Justice Framework, 27 J. Org. BeHav. 537, 539-40 (2006) (theorizing that employee perceptions of corporate social responsibility influence emotions, attitudes, and behaviors).

204. Stephen Brammer et al., The Contribution of Corporate Social Responsibility to Organizational Commitment, 18 Int'L J. Hum. Resource Mgmt. 1701, 1714 ("The empirical results suggest that employee perceptions of corporate social responsibility have a major impact on organizational commitment."). There are three forms of organizational commitment: "affective commitment which denotes 'an emotional attachment to, identification with, and involvement in the organization' . . .; continuance commitment which denotes 'the perceived costs associated with leaving the organization'; and normative commitment 'which reflects a perceived obligation to remain in the organization.'" Id. at 1703.

205. Id. at 1714 .

206. Ante Glavas \& Sandy Kristin Piderit, How Does Doing Good Matter? Effects of Corporate Citizenship on Employees, 36 J. CoRP. Citizenship 51, 64 (2009).

207. See David A. Coldwell et al., The Effects of Person-Organization Ethical Fit on Employee Attraction and Retention: Towards a Testable Explanatory Model, 78 J. Bus. Ethics 611, 614 (2008) ("The essential point is that an individual's attraction to and retention in a company can be at least partly explained by individual and organizational value matches and mismatches and that some of these matches and mismatches reside in perceptions of CSR.").

208. Hae-Ryong Kim et al., Corporate Social Responsibility and Employee-Company Identification, 95 J. Bus. ETHICs 557, 564-65 (2010); Abraham Carmeli et al., The Role of Perceived Organizational Performance in Organizational Identification, Adjustment and Job Performance, 44 J. Mgmt. Stud. 972, 984 (2007). High organizational identification in turn improves job performance. Id.

209. Ante Glavas \& Ken Kelley, The Effects of Perceived Corporate Social Responsibility on Employee Attitudes, 24 Bus. Eтhics Q. 165, 184-85 (2014). 
the lead firm will have to build trust all over again. That, in turn, grants the supplier a stable contractual relationship with a single firm. Stability is an important need for suppliers who produce under tight margins and deadlines for delivery. ${ }^{210}$ Such suppliers deliver their batch to the middlemen (or large suppliers), tier-one suppliers, or sourcing agents. ${ }^{211}$ The batch is then sent to lead firms. ${ }^{212}$ A supplier's survival depends on being flexible and conforming to ever-changing production demands. In addition, survival for a supplier, particularly a small supplier in a competitive industry, is subject to significant volatility arising from economic forces outside its control. ${ }^{213}$ Stability for a supplier can deliver a steady income, promote planning, and encourage the hiring of a consistent workforce. Workers for the supplier can have increased security that their employment will continue beyond the immediate term.

Finally, sustainable practices allow suppliers to lift themselves out of poverty. A supplier, through its successful and sustained interaction with its lead firm, may develop sufficient capabilities that enable it to move up the global supply chain. A supplier initially skilled in raw material manufacturing may develop proficiency of assembly, coordination, quality control, or other more advanced processes. As the supplier moves up the chain, it potentially becomes more tied to the lead supplier, further augmenting the trust and relation-specific investments between the parties. Suppliers performing more sophisticated tasks may also generate greater margins for themselves and be able to provide better salaries and working conditions. The ultimate step may be a supplier's vertical integration with the lead firm, which neutralizes exploitation, prevents haggling, and unifies assets under a single sustainable governance structure. ${ }^{214}$

\section{B. Sustainable Practices in Global Supply Chains Promote Fairness}

Fairness is a fundamental concern of sustainable development, with intragenerational and intergenerational equity essential to sustainable practices. ${ }^{215}$ Fairness in sustainability invokes just access to cultural

210. See Soundararajan \& Brown, supra note 15, at 95-97.

211. See id.

212. See id.

213. Thomas Y. Choi \& Yunsook Hong, Unveiling the Structure of Supply Networks: Case Studies in Honda, Acura, and DaimlerChrysler, 20 J. Operations Mgmt. 469,490 (2002) (discussing examples of small suppliers facing relentless pressure to cut costs).

214. See generally Francine Lafontaine \& Margaret Slade, Vertical Integration and Firm Boundaries: The Evidence, 45 J. ECON. LiTERATURE 629 (2007) (examining optimal conditions and consequences of vertical integration decisions); OLIVER E. WILLiamson, The Economic Institutions of CApitalism 85-130 (1985).

215. Christopher B. Barrett, Fairness, Stewardship and Sustainable Development, 19 Ecological ECON. 11, 12-13 (1996). 
resources and the distribution of welfare. ${ }^{216}$ The perception of fairness is a significant force in supply contracts. ${ }^{217}$ For example, participants in supply chains have a strong aversion to inequality-because fairness concerns regarding resource scarcity and distribution generally have a significant impact. ${ }^{218}$ Consumers will also respond negatively to evidence of price unfairness in the exploitation of others. ${ }^{219}$

Two types of fairness evolve through relation-oriented partnerships. The first type is procedural fairness, which refers to "the perceived fairness of the means used." ${ }^{220}$ Procedural fairness encompasses the criteria for making unbiased, ethical, transparent, and correctable decisions. ${ }^{221}$ Procedural fairness involves the number of safeguards and other opportunities for the participant to engage in a fair process to evaluate the propriety of a particular decision. ${ }^{222}$ These safeguards can include consistent application, freedom from bias, use of accurate and objective information in the decision-making process, incorporation of various stakeholder concerns, and a mechanism to correct flawed outcomes. ${ }^{223}$ Procedural fairness is closely tied to relationbased contracting, with suppliers more likely to alleviate conditions of poverty in procedurally fair environments. ${ }^{224}$ For example, a study of farmers found that procedurally fair conditions of transparent and verifiable product and pricing criteria enabled suppliers to reduce uncertainty and more effectively manage their production process. ${ }^{225}$ Sustainable practices in global supply chains enhance fairness for all participants, but in particular, for organizations at the base of the supply chain.

Procedural fairness is less influential in competitive markets because a dissatisfied firm can simply exit the relationship and choose another partner. However, firms that have made relational-specific in-

216. See David Throsby, Cultural Sustainability, in A Handbook of Cultural Economics 183, 183-84 (Ruth Towse ed. 2003).

217. Elena Katok \& Valery Pavlov, Fairness in Supply Chain Contracts: A Laboratory Study, 31 J. Operations Mgmt. 129, 136 (2013) (showing how fairness concerns influence the behavior of supply chain members); Tony Haitao Cui et al., Fairness and Channel Coordination, 53 MgMt. ScI. 1303, 1309-10 (2007) (similar).

218. Katok \& Pavlov, supra note 217, at 131.

219. Maurice E. Stucke, Looking at the Monopsony in the Mirror, 62 EMORY L.J. 1509, 1557 (2013).

220. Robert Folger \& Mary A. Konovsky, Effects of Procedural and Distributive Justice on Reactions to Pay Raise Decisions, 32 AcAd. Mgmt. J. 115, 115 (1989).

221. Boyd et al., supra note 70, at 343.

222. See Larry A. DiMatteo et al., Justice, Employment, and the Psychological Contract, 90 Or. L. Rev. 449, 466 (2011); Yadong Luo, Procedural Fairness and Interfirm Cooperation in Strategic Alliances, 29 Strat. Mgmt. J. 27, 27 (2008).

223. Katherine V.W. Stone, Procedural Justice in the Boundaryless Workplace: The Tension Between Due Process and Public Policy, 80 Notre Dame L. Rev. 501, 508-09 (2005) (listing key criteria that define procedural fairness).

224. Jorge A. Rodríguez et al., NGOS'Initiatives to Enhance Social Sustainability in the Supply Chain: Poverty Alleviation Through Supplier Development Programs, J. Supply Chain Mgmt., July 2016, at 83, 101.

225. Id. at $100-01$. 
vestments can lose those investments from unfair behavior. Thus, supply chain participants benefit from introducing rules and processes that objectively evaluate conduct. For example, a supplier and lead firm could agree that a supplier may not be dismissed without an opportunity to be heard. This opportunity gives the supplier time to resolve any disagreements before the firm terminates the supplier. Procedural fairness in contract disagreements also gives the supplier notice and an opportunity to be heard. The recognition of someone's dignity and importance through implementation of protective processes enhances feelings of positive social standing and engagement in the relationship overall. ${ }^{226}$ Conversely, disrespect or impolite treatment, such as the denial of procedural fairness, encourages feelings of disconnection and vulnerability by the other party. ${ }^{227}$ Trust and familiarity developed in supply chains discourage denial of such fairness, not only because of the cost of exiting the relationship, but also due to the increased likelihood of supply chain members perceiving one another more humanely.

Procedural fairness need not only be used to curb arbitrary decision-making, but can also be leveraged to encourage positive conduct. Procedural fairness can reward consistent and superlative conformance to deadlines and quality standards with special recognition. This "reward power" is contingent on positive outcomes and encourages internalization of the desired norms between lead firm and supplier. ${ }^{228}$ These processes may impose costs, but they do so for the benefit of increasing loyalty and product quality while discouraging opportunism and defection. Ultimately, greater procedural justice may be more effective than monitoring in increasing supplier compliance. ${ }^{229}$

Distributive fairness refers to "the material outcomes for the various parties of a pattern of allocation." ${ }^{230}$ Outcomes that are distributively fair are expected to narrow, or at least not widen, the existing inequality between the parties. ${ }^{231}$ Distributive fairness can be cultivated through equitable treatment across suppliers, whereby lead firms, through their middlemen, avoid favoritism and make standards objective, achievable, and verifiable. ${ }^{232}$ Suppliers that perform well can be rewarded with awards, bonuses, continued and, perhaps, deep-

226. Tom R. Tyler \& E. Allan Lind, A Relational Model of Authority in Groups, in Advances in Experimental Social Psychology 115, 141 (Mark P. Zanna ed., 1992).

227. Id.

228. See id. at 118.

229. Boyd et al., supra note 70 , at 348 .

230. Bosse et al., supra note 141, at 450; DiMatteo et al., supra note 222, at 466-67.

231. Cf. Richard W. Parker, The Use and Abuse of Trade Leverage to Protect the Global Commons: What We Can Learn from the Tuna-Dolphin Conflict, 12 Geo. INT'L ENVTL. L. REV. 1, 80 (1999) (describing substantive fairness in international law context).

232. See Baskaran et al., supra note 15 , at 648-51 (summarizing literature on supplier evaluation methods). 
ening partnerships, and being entrusted with more critical, complex, or demanding work. Through repeated exchange, sustained communication, and trust, relational contracts facilitate this fairness that encourages parties to share knowledge, sustain commitment, and plan for the long-term. ${ }^{233}$ By contrast, firms that impose distributive unfairness in supply chains risk retribution in the form of financial and social penalties. Distributive unfairness contributes significantly to inefficiencies and coordination failures in supply chains. This is especially problematic when fairness concerns are not shared amongst members of the supply chain. ${ }^{234}$

Although normative concepts, such as fairness and justice, primarily benefit the supplier, they also have value for the lead firm. Fairness also has positive impacts on supply chain performance ${ }^{235}$ and is influenced by contract design. ${ }^{236}$ The increased complexity of a contract, which can be useful in defining contingencies and future planning, generates improved performance when procedural fairness is present. ${ }^{237}$ When substantive fairness is part of a contract, it encourages contractual stability and recurring performance of the contract's terms. ${ }^{238}$ Fairness in supply chains also enhances the loyalty of members within that supply chain to increase continued participation. ${ }^{239}$ Authors studying fairness concluded that, "fairness is critical to effective governance" and should have an impact on contract performance for both parties. ${ }^{240}$ Unfair behavior in supply chains, by contrast, can be the source of defections and punitive behavior that can have a boomerang effect against the lead firm. ${ }^{241}$

233. Griffith et al., supra note 162, at 94-95; Yi Liu et al., How Does Justice Matter in Achieving Buyer-Supplier Relationship Performance?, 30 J. Operations Mgmt. 355, 364 (2012).

234. See Katok \& Pavlov, supra note 217, at 136.

235. Id.; Christoph H. Loch \& Yaozhong Wu, Social Preferences and Supply Chain Performance: An Experimental Study, 54 Mgmt ScI. 1835, 1842 (2008).

236. See Teck-Hua Ho et al., Distributional and Peer-Induced Fairness in Supply Chain Contract Design, 23 Production \& Operations Mgmt. 161, 173 (2014).

237. Laura Poppo \& Kevin Zheng Zhou, Managing Contracts for Fairness in BuyerSupplier Exchanges, 35 Strategic Mgmt. J. 1508, 1512, 1521 (2014). See generally Kevin E. Davis \& Helen Hershkoff, Contracting for Procedure, 53 WM. \& MARY L. REv. 507, 511 (2011) (exploring the justice and spillover implications of "contract procedure" which the authors define as "the practice of setting out procedures in contracts to govern disputes that have not yet arisen.").

238. Poppo \& Zhou, supra note 237, at 1512-13, 1521-22.

239. Thani Jambulingam et al., How Fairness Garners Loyalty in the Pharmaceutical Supply Chain, 3 Int'l J. Pharmaceutical \& Healthcare Marketing 305, 315 (2009).

240. Poppo \& Zhou, supra note 237, at 1521.

241. See Nirmalya Kumar et al., Interdependence, Punitive Capability, and the Reciprocation of Punitive Actions in Channel Relationships, 35 J. MARKeTING Res. 225, 231-32 (1998). 


\section{CONClusion}

While sustainable global supply chains are an aspiration for millions, sustainable supply chains are still far from a consistent reality. One of the most important frictions preventing sustainable practices is the absence of trust between lead firms and suppliers. In the absence of trust, enforcing sustainable standards is difficult and costly, with lead firms having a limited ability to gather evidence and suppliers having readily available mechanisms to circumvent sustainable obligations.

This Article proposes a method by which lead firms and suppliers can foster relation-based arrangements, even when trust is absent between the parties. We draw on the concepts of unilateral initiatives and trust to explore how different types of trust can develop over time between lead firms and suppliers. This trust can eventually enable them to make sustainable investments with a reduced risk of shirking or hold-ups. Sustainable practices become a value-generating asset for the supply chain, enabling members of the supply chain to outperform rivals. Sustainable practices also enhance fairness for all supply chain members, especially those most vulnerable at the base of the supply chain.

Global supply chains are a powerful value-creating mechanism. However, they are also vulnerable to exploitation of suppliers and mismanagement of resources. This Article proposes a mechanism by which supply chain participants in hostile environments can de-escalate their suspicions, build productive relationships, and enhance value and justice for all parties concerned.

Figure 1. Building Trust and Sustainability in Global Supply Chains

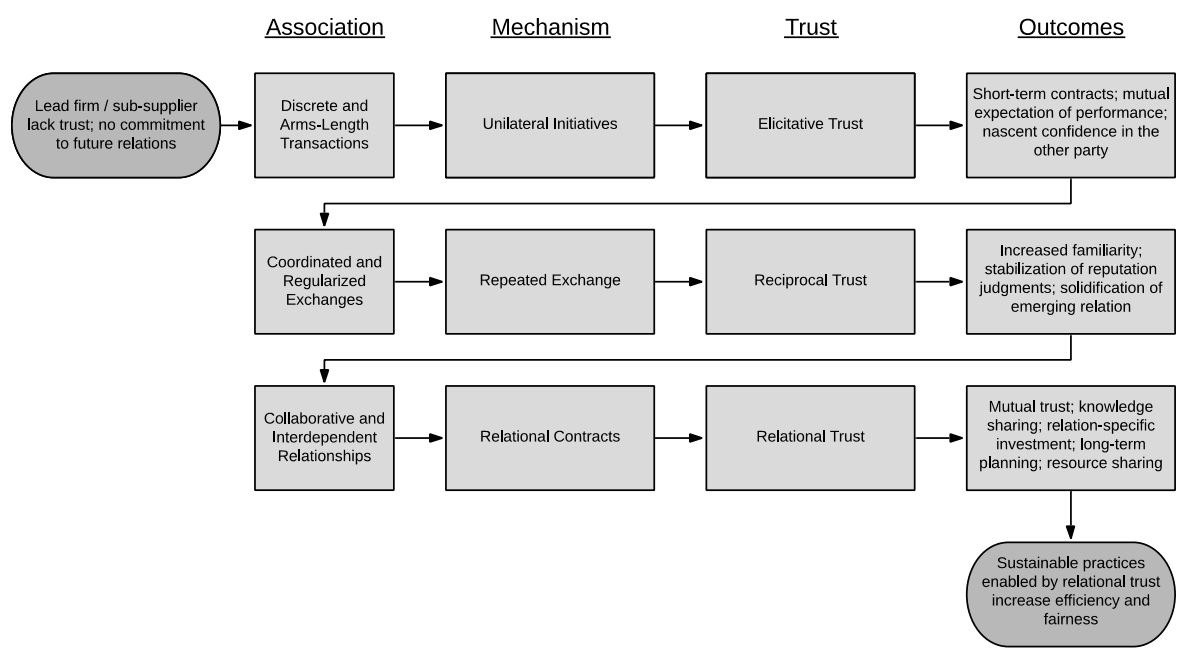

